\title{
Acute Phase Reactants as Novel Predictors of Cardiovascular Disease
}

\author{
M. S. Ahmed, ${ }^{1,2}$ A. B. Jadhav, ${ }^{1,2}$ A. Hassan, ${ }^{1}$ and Qing H. Meng ${ }^{3}$ \\ ${ }^{1}$ Department of Medicine, Royal University Hospital, University of Saskatchewan, 107 Wiggins Road, Saskatoon, SK, Canada S7N 5E5 \\ ${ }^{2}$ Department of Pharmacology, University of Saskatchewan, 107 Wiggins Road, Saskatoon, SK, Canada S7N 5E5 \\ ${ }^{3}$ Department of Pathology and Laboratory Medicine, Royal University Hospital, University of Saskatchewan, \\ 103 Hospital Drive, Saskatoon, SK, Canada S7N OW8
}

Correspondence should be addressed to Qing H. Meng, qing.meng@usask.ca

Received 27 January 2012; Accepted 1 April 2012

Academic Editors: N. Ortego-Centeno and S. Pender

Copyright () 2012 M. S. Ahmed et al. This is an open access article distributed under the Creative Commons Attribution License, which permits unrestricted use, distribution, and reproduction in any medium, provided the original work is properly cited.

Acute phase reaction is a systemic response which usually follows a physiological condition that takes place in the beginning of an inflammatory process. This physiological change usually lasts 1-2 days. However, the systemic acute phase response usually lasts longer. The aim of this systemic response is to restore homeostasis. These events are accompanied by upregulation of some proteins (positive acute phase reactants) and downregulation of others (negative acute phase reactants) during inflammatory reactions. Cardiovascular diseases are accompanied by the elevation of several positive acute phase reactants such as C-reactive protein (CRP), serum amyloid A (SAA), fibrinogen, white blood cell count, secretory nonpancreatic phospholipase 2-II (sPLA2II), ferritin, and ceruloplasmin. Cardiovascular disease is also accompanied by the reduction of negative acute phase reactants such as albumin, transferrin, transthyretin, retinol-binding protein, antithrombin, and transcortin. In this paper, we will be discussing the biological activity and diagnostic and prognostic values of acute phase reactants with cardiovascular importance. The potential therapeutic targets of these reactants will be also discussed.

\section{Introduction}

Since 1930, investigators began to investigate the distant changes occur away from the original site(s) of inflammatory process. The discovery of C-reactive protein (CRP) by Tillett and Francis [1] opened this door wide. These distant systemic changes have been referred to as acute phase response regardless whether they follow an acute or a chronic inflammatory process. Acute phase responses are divided according to the concentrations of many plasma proteins known as acute phase proteins. Acute phase proteins can be defined as those whose plasma protein concentration increase with inflammatory reaction (positive acute phase proteins). However, negative acute phase proteins are those whose plasma protein concentrations decrease with inflammatory reaction. Interleukin- (IL-) 6 is the major stimulator of the production of most acute-phase proteins. Acute phase proteins predict and/or reflect the intensity of cardiovascular diseases. Cardiovascular diseases are accompanied by the elevation of several positive acute phase reactants such as CRP, serum amyloid A (SAA), fibrinogen, white blood cell count, secretory nonpancreatic phospholipase 2-II (sPLA2II), ferritin, and ceruloplasmin. Cardiovascular diseases are also accompanied by the reduction of negative acute phase reactants such as albumin, transferrin, transthyretin, retinol-binding protein, antithrombin, and transcortin. The concentration of acute phase reactants in plasma varies according to the severity of the cardiovascular disorder and also due to the differences of pattern of production of the individual protein. This explains why an individual biomarker such as CRP elevates in plasma while another under the same category (such as SAA) does not.

\section{Positive Acute Phase Reactants}

2.1. C-Reactive Protein (CRP). In 1930, Tillett and Francis described an acute phase reactant in the serum of patients 
with pneumonia that they called CRP because of its precipitation with Pneumococcal C-polysaccharide [1]. The gene for CRP has been localized to chromosome 1 [2] and codes for a mature, 206 amino acid polypeptide [3]. The physiological role for human CRP is unknown [4]. CRP is a member of the pentraxin family of proteins and comprises five identical polypeptide chains in a pentameric structure [5]. CRP has a half-life of approximately 19 hours and its plasma levels are determined predominantly by its rate of synthesis in the liver, although CRP is also produced by other cells such as adipocytes [6].

2.1.1. CRP as an Inflammatory Agent. CRP is an acute phase protein $[7,8]$ produced in the liver in response to interleukin- (IL-) 6 which is stimulated, in turn, by tumour necrosis factor- $\alpha$ (TNF- $\alpha$ ) and IL-1 $[8,9]$.

Recent studies suggest that CRP plays a pivotal role in many aspects of atherogenesis including LDL uptake by macrophage, release of proinflammatory cytokines, expression of monocyte chemotactic protein-1, intercellular adhesion molecule-1, and vascular cellular adhesion molecule1 [10-12]. Activation of inflammation and the acute phase reaction appear to play an important role, not only in the pathogenesis of atherosclerosis, but also in the initiation of the acute coronary syndrome (ACS) $[13,14]$. Cesari et al. suggested that the inflammatory markers CRP, IL-6, and TNF- $\alpha$ are independent predictors of cardiovascular events in older persons [14].

2.1.2. Diagnostic Value. Although CRP is a nonspecific inflammatory marker which may not be a diagnostic marker for cardiac injury but it is a strong independent predictor for cardiovascular risk and events. Epidemiological studies and clinical trials have found that CRP is a strong independent predictor of future cardiovascular risk [15]. Several large epidemiological studies have suggested that CRP measurement predicts the risk of future CV events [16-19] although other investigators failed to identify CRP as a significant independent risk factor [20,21]. CRP is also an early ischemic marker and elevated CRP is predictive of future adverse events [22, 23]. High-sensitivity CRP (hs-CRP) rises acutely after tissue injury, including myocardial infarction (MI). Intense cytokine production and inflammatory cell infiltration occur in the area of ischemia and necrosis. This increase of hs-CRP levels, in part, correlates with infarct size $[24,25]$ and with a higher risk of cardiac rupture $[26,27]$. In short-term studies of patients with ACS, high CRP concentrations have been shown to be predictive of death, but not recurrent AMI $[28,29]$. There are few studies assessing the long-term risks of an elevated CRP in the ACS population [30-34]. CRP levels are influenced by additional factors such as aging, gender, ethnicity, obesity, diabetes, estrogen use, smoking, hypertension, and autoimmune diseases [8]. Serum levels of CRP can increase 1000-fold in febrile illnesses, various inflammatory states, and trauma [35]. CRP can be also used for patients screening in the primary prevention population [36]. Ockene et al. indicated that CRP is generally expressed at low levels $(<1 \mathrm{mg} / \mathrm{L})$ in healthy adults and levels remain relatively stable in the absence of an acute inflammatory stimulus [37]. Patients with unstable angina and CRP $>3 \mathrm{mg} / \mathrm{L}$ at discharge are more likely to be readmitted for recurrent cardiovascular instability or MI within 1 year [38]. Under acute conditions, concentrations of C-reactive protein increased during the first 6 to 8 hours and can reach peak levels approaching $300 \mathrm{mg} / \mathrm{L}$ after approximately 48 hours [39].

Pietilä et al. indicated that hs-CRP measurement is the strongest correlative factor for future clinical events due to arterial inflammation, myocardial infarction, unstable angina, stroke, and peripheral vascular disease in both diseased and apparently healthy asymptomatic patients [40]. The CRP plasma level also is the best risk assessment in patients with either stable or unstable angina, long term after myocardial infarction, and in patients undergoing revascularization therapies [41]. One study showed the only independent cardiovascular risk indicators using multivariate, age adjusted and traditional risk analysis were CRP and Total/HDL cholesterol ratio. If CRP, IL-6, and ICAM- 1 levels are added to lipid levels, risk assessment can be improved over lipids alone. Moreover, serum CRP may indicate the vulnerability of the plaque [40].

2.1.3. Prognostic Value. A growing body of studies suggest that elevation of hs-CRP levels predicts a poor cardiovascular prognosis [42]. The extent of the inflammatory response to injury appears to have prognostic significance, which is independent of the extent of myocardial injury. hs-CRP response after MI has been shown to predict future CHD morbidity and mortality independent of infarct size [43].

CRP is also a predictor of incident type 2 diabetes. As well, it adds a prognostic information on vascular risk at all levels of the metabolic syndrome [44].

2.1.4. CRP Measurement. As a protein, CRP is quite stable when stored at $-70^{\circ} \mathrm{C}$. It was shown that reference intervals for hs-CRP determined by using fresh serum samples were identical to those obtained by using samples, from a similar population, that were stored for $4.5 \mathrm{yr}$ [45].

When CRP was used primarily for measuring states of extremely active inflammation, such as sepsis or arthritis, values of $50-100 \mathrm{mg} / \mathrm{L}$ are most relevant [46]. Until the late 1970s, CRP was measured using qualitative or semiquantitative laboratory technique, most commonly latex agglutination, which precluded its use as differential diagnostic test because any degree of inflammation produced positive results [47].

Although most of the currently CRP is measured by high sensitive methodologies (hs-CRP) such as immunoturbidimetry and immunonephelometry, preanalytic and analytic variations still exist [48]. The detection range of these assays spans from 3 to well over $200 \mathrm{mg} / \mathrm{L}$ [8]. These methods still do not have the sensitivity needed for the use of CRP in the assessment of future coronary risk [8]. The most recent hs-CRP assays utilize either antibodies that are labelled with an enzyme (ELISA) or a fluorescent compound or polystyrene beads-coated antibodies to achieve the desired sensitivity [8]. 
Continuation in improvement of its sensitivity, precision, accuracy, and standardization is critical. The interpretation, defining cut-off values, and integration into screening panel are essentials in guidance of clinical practice.

The American Heart Association and the Centers for Disease Control and Prevention (AHA/CDC) issued guidelines for the utility of this marker in the primary prevention setting and in patients with ACS [43].

The guideline recommended from the laboratory aspects the cut-off values for risk assessment: hs-CRP concentration $<1 \mathrm{mg} / \mathrm{L}$ are considered low risk, $1-3 \mathrm{mg} / \mathrm{L}$ intermediate risk, and $>3 \mathrm{mg} / \mathrm{L}$ are in high risk.

\subsection{Serum Amyloid A (SAA)}

2.2.1. Biological Activity. SAA is an acute phase reactant protein and is secreted by macrophages, vascular smooth muscle cells, and endothelial cells $[49,50]$. SAA is also expressed in adipose tissue and there is an emerging body of research investigating its role in adipose inflammation and insulin resistance and diabetes [51]. Thus, the association of SAA with CVDs may be either direct from effects of SAA on atherosclerosis, or indirect via effects of SAA on clinical conditions known to confer increased risk for CVDs [51]. SAA is synthesized primarily in liver in response to stimulation by cytokines such as TNF-a, IL-1, and IL-6 [51]. The SAA family comprises acute-phase isoforms (SAA- 1 and SAA-2) and a constitutive isoform (SAA-4) [51]. SAA-3 is an isoform that shares approximately $60 \%$ homology with the acute-phase isoforms but it is not expressed in humans and it does not appear to be a component of the acute-phase response [51].

2.2.2. SAA as a Proatherogenic Agent. SAA promotes the chemotaxis for monocytes and neutrophils, stimulation of the production of other proinflammatory cytokines such as IL- $1 \mathrm{~b}$ and TNF-a, and induction of the matrix metalloproteinases (MMPs) $[52,53]$. It was also confirmed that SAA promotes thrombosis by increasing tissue factor [54, 55]. SAA alters HDL function by impairing reverse cholesterol transport (RCT) [51]. RCT is well known to be promoted by HDL which plays a pivotal role in lipid metabolism [51]. It was determined that SAA could potentiate atherogenesis at a number of stages. (1) SAA is chemotactic for neutrophils and monocytes. (2) SAA-carrying LDL may have greater proteoglycan-binding affinity leading to increased retention. (3) SAA stimulates the synthesis of biglycan and increases its binding affinity for LDL. (4) SAA can stimulate the production of other proinflammatory cytokines, exacerbating the vascular inflammation. (5) SAA can induce matrix metalloproteinases (MMPs) which can lead to the destabilization of the developing atherosclerotic plaque [51].

2.2.3. Diagnostic Value. SAA along with CRP are used clinically as inflammatory markers [49]. These proteins usually respond in parallel to a given stimulus; however, the magnitude of the SAA response has been found to be greater than that of CRP [56-58]. Some studies have shown that SAA levels increase with higher degrees of inflammation, even in some noncardiovascular inflammatory conditions, whereas CRP levels remain normal $[59,60]$. Thus, SAA is considered more sensitive and useful than CRP as a marker of acute inflammatory response $[59,60]$. Casl et al. have conducted a study on early recognition of acute kidney allograft rejection. Their results showed that acute renal allograft rejection induces a dramatic acute phase response [61]. Peak levels of SAA were increased up to 1000 -fold above the normal and those of CRP about 100-fold of the normal [61]. An excellent correlation between kidney allograft rejection and SAA reaction was found in this study and monitoring of SAA concentrations in patients with kidney allograft was recommended as a valuable aid in the early diagnosis and prediction of acute allograft rejection [61]. Kosuge et al. indicated that patients with elevated SAA levels had higher rates of adverse events (death, myocardial infarction, or urgent target-vessel revascularization) at 30 days, irrespective of whether CRP was elevated [49]. In contrast, elevated CRP levels with normal SAA were not associated with adverse outcomes at 30 days [49]. The overall conclusion is that SAA is more sensitive than CRP in responding to cardiovascular and noncardiovascular events.

2.2.4. Prognostic Value. A study has been conducted by Katayama et al. demonstrated a significant association between the SAA level in the acute phase of AMI and clinical prognosis [62]. It also indicated that SAA can predict cardiac death [62]. This study also confirmed a significant positive correlation between the levels of SAA in acute phase AMI and the levels of hs-CRP and peak CK [62]. Liuzzo et al. have also demonstrated that elevation of CRP and SAA at the time of hospital admission predicts a poor outcome in patients with unstable angina [63].

2.2.5. Measurement of $S A A$. Kosuge et al. have described the measurement of SAA by latex-enhanced nephelometric immunoassay on a Hitachi 7600 autoanalyzer (Hitachi, Tokyo, Japan) [49]. Casl et al. have established a quantitative determination of SAA by micro-ELISA method with sensitivity of $0.1 \mathrm{mg} / 1$ and precision expressed with CVs between 1.6 and $4.2 \%[61]$.

2.3. Fibrinogen. Fibrinogen is a positive acute phase reactant. The association between the high concentration of fibrinogen and risk of cardiovascular disease is well established. The relation was first reported in preliminary results from the Northwick Park Heart Study in 1980 [64].

2.3.1. Biochemistry and Biological Activity. Fibrinogen is a symmetrical glycoprotein composed of six polypeptide chains of three types: two $\mathrm{A} \alpha$, two $\mathrm{B} \beta$, and two $\gamma$ [65]. These chains are held together by disulphide bridges [66]. The total molecular weight of high molecular weight (HMW) fibrinogen is 340,000 daltons [65].

There are several mechanisms by which fibrinogen may increase cardiovascular risk. First, it binds specifically to activated platelets via glycoprotein IIb/IIIa, contributing 
to platelet aggregation. Second, increased fibrinogen levels promote fibrin formation. Third, it is a major contributor to plasma viscosity. Finally, it is an acute-phase reactant that is increased in inflammatory states [67].

2.3.2. Diagnostic Value. The role of plasma fibrinogen as an independent cardiovascular risk factor has been documented [68]. Occlusive thrombi are found in most cases of acute myocardial infarction (MI), sudden cardiac ischemic death, and unstable angina pectoris $[69,70]$. Thrombosis is recognized as the central mechanism of these atherosclerotic complications $[68,69]$.

Plasma fibrinogen is also associated with traditional risk factors such as smoking, obesity [67]. Fogari et al. found that fibrinogen levels increased with the number of cigarettes smoked. Fibrinogen levels also quickly fall after smoking cessation, suggesting that this rapid fall in level may be a mechanism for the reduction in cardiovascular risk after smoking cessation [71].

Association between the elevation in fibrinogen level and obesity increases the risk of cardiovascular disease [67]. A reduction in body mass index after a low-calorie diet for 6 months has been accompanied by a fall in fibrinogen level [72]. The Prospective Cardiovascular Munster (PROCAM) study found that individuals who had LDL and fibrinogen levels in the highest tertile had a 6.1-fold increase in coronary risk compared with those in the lowest tertile [73]. The event rate was significantly lower when fibrinogen levels were in the lowest tertile even though LDL remained in the highest tertile [67].

Association between diabetes and increased plasma fibrinogen levels was found to cause platelet hyperreactivity as fibrinogen is acting as a cross bridge between platelets [67]. This might explain why poor diabetic control is particularly associated with higher levels of fibrinogen [74].

Gil et al. have determined that increased plasma levels of fibrinogen as an acute phase reactant marker and associated with unfavorable outcome of acute coronary syndrome (ACS) [75].

2.3.3. Prognostic Value and Measurement. Shi et al. have demonstrated that elevated level of plasma fibrinogen is associated with a worse long-term prognosis in patients who have ACS [76].

There are four main methods used to measure fibrinogen concentration: clotting rate assays; clottable protein assays; heat-/salt-precipitation and immunological assays. The results obtained can be affected by the assays used, the fibrinogen heterogeneities described above, and other plasma constituents [65].

2.4. White Blood Cell (WBC) Count. It was well established that elevated WBC count is associated with systemic bacterial infections and during inflammatory processes.

2.4.1. Relationship between Total Leukocyte Count and Cardiovascular Disease and Associated Risk Factors. Rana et al. indicated that coronary heart disease (CHD) is associated with elevated total leukocyte count [77]. The association of leukocyte count with CHD was first reported in the 1920 s [78]. A clear and positive correlation between the leukocyte count and risk of CHD has been established in several prospective studies conducted in CHD-free subjects [79-83]. This correlation appears to persist even after adjustment for other risk factors [84-86]. As smoking is a CHD risk factor, WBC count is higher in smokers compared to non- smokers [87]. Madjid et al. confirmed elevated WBC count as an independent risk factor for $\mathrm{CHD}$ [87]. A correlation between baseline leukocyte count and the incidence of MI has been also described [87].

WBC count has been also counted as a prognostic indicator in subjects with stable $\mathrm{CHD}$ after a previous MI within 3 or 6 months [88, 89]. The two conditions were associated with elevated total leukocyte count with an increased risk of re-infarction or death [87]. In patients with acute MI, leukocyte count was significantly high at presentation [87]. In a logistic regression model, leukocytosis was an independent predictor of acute MI [87].

In untreated patients with hypertension, elevated leukocyte count was associated with subsequent cardiovascular morbidity independent of blood pressure levels, smoking, diabetes, lipid levels, and established markers of target organ damage including electrocardiographic left ventricular hypertrophy and glomerular filtration rate [90]. Several cross-sectional studies have shown a positive relationship between systolic blood pressure (SBP) and inflammatory markers including CRP and WBC count [91]. They demonstrated that increased SBP even within the normotensive range is associated with increased WBC count [91]. They indicated that this association persisted after adjustment for age, gender, smoking status, BMI, physical activity level, cholesterol/HDL-C ratio, and cholesterol-lowering medications [91]. An elevated WBC count may also be a marker for a state characterized by increased catecholamine levels or sympathetic nervous system activity [92] which can raise blood pressure and may eventually result in sustained hypertension [93].

2.4.2. Relationship between Differential Leukocyte Count and Cardiovascular Disease and Associated Risk Factors. Considering differential leukocyte cell count, a correlation was found between moderately elevated eosinophil count and increased risk of disease, as well as between neutrophil, eosinophil, and monocyte (but not lymphocyte) counts and the incidence of disease [87]. In a case-control study, eosinophil counts were significantly higher in those who had severe vasospastic angina pectoris than in those who had mild vasospastic angina pectoris, stable angina, or no angina [94]. After treatment with antianginal drugs, however, the eosinophil counts decreased to control levels. It was also reported by Biasucci et al. that the number of neutrophils was much higher in the patients with acute MI than in those with UA or stable angina [95]. It was observed by Rana et al. that granulocyte count is consistently associated with increased risk for CHD [77]. Rana et al. also revealed that there is no association of monocyte count or lymphocyte count and risk of CHD and CVD [77]. Granulocytes can release a variety of 
mediators of tissue injury that cause neutrophil stimulation giving rise to additional products with enhanced endothelial injury [96]. Neutrophils can directly cause damage to coronary vascular endothelium by adherence-dependent mechanisms involving the early adhesion molecule $P$ selectin [97]. Granulocytes also release highly cytotoxicfree oxygen radicals and proteolytic enzymes [98]. ROS may influence vascular tone either indirectly by inactivating endothelium-derived relaxing factor [99] and reducing the release of prostacyclin [100] or directly by promoting smooth muscle cell contraction [101]. This may result in the loss of vasodilator, antithrombotic, and antiatherogenic properties of the vascular endothelium [102]. The overall effect is elevating systolic blood pressure even within normotensive range. Intense neutrophil activation in unstable angina or AMI, as manifested by morphologic changes in neutrophils and elastase release, may relate to ongoing in vivo cellular activation [103]. Another study has demonstrated that increased neutrophil platelet adhesion may contribute to neutrophil activation in unstable angina [104]. On the other hand, Schillaci et al. suggested a role for monocytes in atherogenesis and vascular thrombosis (through an interaction with platelets) by giving rise to foamy macrophages and ROS [90]. One retrospective study of patients with coronary artery disease (CAD) showed that five-year survival was significantly better for patients who had a normal as compared with a low relative lymphocyte count (92\% versus $83 \%)$ [105].

\subsection{Secretory Nonpancreatic Type II Phospholipase A2 (sPLA2-II)}

2.5.1. Chemical and Biological Properties. sPLA2-II is a positive acute phase reactant with properties to catalyze the production of lipid mediators leading to impaired vasodilator function in patients with documented CAD [106].

PLA2 are ubiquitous enzymes that hydrolyse the $s n$-2acyl bond of cell membrane phospholipids and lipoproteins and yield free fatty acids and lysophospholipids, precursors of various proinflammatory lipid mediators, including leukotrienes, prostaglandins, and platelet-activating factor $[106,107]$. PLA2 exist in many isoforms including the $14 \mathrm{KDa}$ secretory phospholipase A II (sPLA2) and the 85 KDa cytosolic phospholipase A II (cPLA2) [108]. sPLA2$\mathrm{I}$ is described as pancreatic PLA2 since it is expressed in high amounts in pancreas [108]. Proinflammatory cytokines lead to an increase in expression and secretion of sPLA2-II from different organs and tissues, including atherosclerotic plaques [109] where sPLA2 was found to be highly expressed $[109,110]$. Extracellular sPLA2-II is mainly localized at sites where it hydrolyses phospholipids from lipoproteins and lipid aggregates retained in the extracellular matrix of the arterial wall. This may be a potential mechanism for in situ release of proinflammatory lipids, free fatty acids and lysophosphatidylcholine in regions of apo-lipoprotein $\mathrm{B}$ accumulation, which are abundant in atherosclerotic lesions [111]. Additionally it was documented that sPLA2 induces the expression of chemokines and adhesion molecules in microvascular endothelium [112].

2.5.2. Diagnostic Value. Kugiyama et al. have demonstrated that elevated serum level of sPLA2-II is an independent risk factor for CAD [113]. They also indicated that the increase in sPLA2-II serum levels is a predictor of developing clinical coronary events in patients with CAD [113]. Fichtlscherer et al. have referred this association to the fact that elevated serum sPLA2-II causes impairment in systemic endothelial vasodilator function [106]. They also confirmed that sPLA2II and CRP are sharing this function in terms of being independent predictors of vascular response to acetylcholine [106]. They concluded that both sPLA2-II and CRP can serve as mediators of endothelial dysfunction $[106,114]$. The correlation with CRP is much stronger than that with WBC count [115].

In a large cohort study over 4 years on patients with CHD, a single measurement of sPLA2-II mass and activity at baseline was associated with recurrent events even after controlling other risk factors that might increase risk for CVD. sPLA2-II mass and activity were strongly correlated but the association of mass with secondary CVD event was even stronger [114].

2.5.3. sPLA2-II as a Therapeutic Target. LY315920 ([[3(aminooxoacetyl)-2-ethyl-1-(phenylmethyl)-1H-indol-4-yl] oxy] acetate), a pharmacological drug that functions as a selective stoichiometric inhibitor of the catalytic activity of sPLA2-II [108]. LY315920 has been administered orally and intravenously in transgenic mice expressing human sPLA2-II [108]. LY315920 has inhibited the sPLA2-II serum activity in these mice [108]. Some other drugs have several biological and pharmacological properties including the inhibition of sPLA2-II serum activity such as NSAIDs (Alminoprofen (a member of the phenylpropionic acid class of drugs), aspirin [115, 116], heparin [117], and indomethacin [115]). Chemically modified tetracyclines, devoid of antimicrobial properties also inhibit the activity of serum sPLA2-II [118]. Cholesterol lowering agents such as simvastatin and atorvastatin causes a reduction in sPLA2-II [119].

\subsection{Serum Ferritin}

2.6.1. Biological Activity. Ferritin, which is the major iron storage protein, plays a key role in iron metabolism [120]. Serum ferritin senses the body iron stores and serves as the early sensitive marker for iron deficiency. Serum ferritin is elevated as iron stores rises. Serum ferritin differs markedly from tissue ferritin in molecular weight, iron and carbohydrate content, subunit size, amino acid sequence, and possibly is encoded by genes distinct from those of tissue ferritin [121, 122]. Ferritin maintains up to 4500 atoms of hydrolyzed and polymerized atoms in a soluble form within a protein shell with a hollow interior of approximately $90 \AA$ $[123,124]$. Ferritin binds iron in a catalytically inactive manner; accordingly, oxidative reactions cannot be promoted by iron bound to ferritin but by free iron [125]. Tran et al. 
reported that the synthesis of ferritin is driven by cytokines [126]. Serum ferritin is positively correlated with serum CRP concentrations $[121,127]$. Serum ferritin also increases with increasing BMI [128], possibly a result of higher IL-6 levels in heavier subjects. Serum ferritin is inversely proportional to aspirin intake, as persons with higher aspirin use have lower serum ferritin $[121,129]$ providing the property of aspirin as an anti-inflammatory agent. Many solid conclusions come to the finding that serum ferritin is a positive acute phase reactant and is strongly associated with inflammatory processes including heart diseases and diabetes.

\subsubsection{Is There an Association between Serum Ferritin and} Cardiovascular Disease? The association between serum levels of ferritin and cardiovascular disease is still controversial and requires further investigation. From a study on Finnish subjects (a total of 1931 unselected men) without symptoms of CHD during an average followup for 3 years, It was reported that 2.2 times greater levels of cardiovascular disease were observed in the group with high serum iron (indicative of elevated serum ferritin) compared to the group with low serum iron $[130,131]$. Serum ferritin was reported to be associated with cardiovascular disease and cardiovascular mortality [132]. Salonen et al. also reported that increases in serum ferritin accelerate the oxidation of LDL-cholesterol [131]. This oxidized LDL-cholesterol-induced inflammation in blood vessels, including the progression of atherosclerosis. This role is thought to be due to prooxidant properties [130]. In patients with serum ferritin concentrations $>200 \mathrm{ng} / \mathrm{mL}$, the risk of myocardial infarction was 2.2 times greater than the patients with serum ferritin levels $<200 \mathrm{ng} / \mathrm{mL}$ [130]. This indicated that serum ferritin indirectly enhances the role of LDL-cholesterol in the induction of cardiovascular diseases [130]. This role is further enhanced by the elevation of hsCRP accordingly [130].

In a prospective study performed in a French population, however, Galan et al. failed to find a positive association between serum ferritin and ischemic heart disease [133]. These findings matched well with the suggestions of Sempos et al. [134], 5 years earlier, as the results from the two studies did not support the hypothesis that positive body iron stores, as measured by serum ferritin, are associated with an increased risk of CVD, CHD, or MI death.

Dominguez-Rodriguez et al. suggested even more extreme finding that major adverse cardiovascular events is associated with lower serum ferritin levels in a study on a total of 196 and 30 days followed-up patients with a first non-ST elevation ACS [135]. Their observation was supported by an in vitro study that iron deficiency enhances atheroma inflammation through p38 mitogen activated protein kinase-nuclear factor- $\kappa \mathrm{B}$-extracellular matrix metalloproteinase inducer/matrix metalloproteinase- 9 pathway [136].

\subsection{Serum Haptoglobin}

2.7.1. Biological Activity and Structure. Serum Haptoglobin (Hp) has been identified as a positive acute phase reactant.
$\mathrm{Hp}$ is an abundant plasma protein which binds with high affinity to hemoglobin $[137,138]$. The binding of Hp to hemoglobin can detoxify hemoglobin released into circulation during in vivo hemolysis. The binding of $\mathrm{Hp}$ to hemoglobin serves to decrease the ability of iron derived from hemoglobin from carrying out oxidative reactions providing that the heme iron in hemoglobin is a very potent oxidant [139]. In other words, Hp function is binding and scavenging of free hemoglobin through the liver or circulating monocytes $[140,141]$. In man, two alleles at the Hp genetic locus denoted 1 and 2 exist [137]. The protein product of the $\mathrm{Hp} 2$ allele is defective in its ability to block oxidative reactions mediated by iron-derived hemoglobin [137]. The Hp 1-Hb complex is relatively redox inert, while the $\mathrm{Hp} 2-\mathrm{Hb}$ complex contains non-transferrin bound redox-active iron [142]. Boretti et al. found that $\mathrm{Hp}$ binding to $\mathrm{Hb}$ is sufficient to prevent the generation of oxidant species from cell-free $\mathrm{Hb}$ that would otherwise mediate hypertension and other adverse vascular outcomes [143]. Interestingly, Boretti et al. also showed that Hpbound $\mathrm{Hb}$ has a very high oxygen affinity and the $\mathrm{Hp}$ $\mathrm{Hb}$ complexes stimulate the production of the endogenous antioxidant NO from nitrite $[143,144]$. In addition, the heme-binding protein hemopexin has evolved to mop up the toxic porphyrin heme ring released from decomposing cell free $\mathrm{Hb}$, and heme-metabolizing enzymes, such as heme oxygenase-1, provide a functional antioxidant effect that is protective to vascular health [145]. Finally, plasma transferrin protein sequesters and safely transports elemental iron released from the heme ring, one of the most oxidative substances in the human body [145].

2.7.2. Hp-Cardiovascular Disease Association. It was determined in many multiple independent longitudinal studies that the $\mathrm{Hp}$ genotype is an independent determinant of the risk of incident cardiovascular disease in individuals with diabetes mellitus (DM) [146-151]. These studies have shown that DM individuals with the Hp 2-2 genotype have a 2-5-fold increased risk of MI, stroke, and cardiovascular death as compared to $\mathrm{Hp} \mathrm{1-1} \mathrm{or} \mathrm{Hp} \mathrm{2-1} \mathrm{individuals.} \mathrm{It}$ was also demonstrated that $\mathrm{Hp}$ phenotype is predictive of development of microvascular complications in DM [152]. They found that patients who are homozygous for the $\mathrm{Hp}$ 1 allele are at decreased risk for developing retinopathy and nephropathy [152]. This effect, at least for nephropathy, has been observed in both type 1 and type 2 DM [153]. Furthermore, the Hp phenotype may be predictive of development of macrovascular complications in DM [152]. Hp can also bind to HDL (most likely via an interaction with helix 6 of ApoA1) and thereby serve to tether hemoglobin to HDL [137]. In Hp 2-2 DM individuals, there is impairment in the clearance of $\mathrm{Hp}$-hemoglobin due to a decreased uptake of the complex by the CD163 Hp-hemoglobin scavenger receptor present on monocytes and kupfer cells [137]. HDL in these Hp 2-2 DM individuals is dysfunctional in terms of its ability to promote reverse cholesterol transport which is believed to be the primary function of HDL [137]. It was also demonstrated that development of restenosis after 
percutaneous coronary angioplasty is significantly decreased in DM patients with the 1-1 Hp phenotype [154]. On contrary, Bacquer et al. found that $\mathrm{Hp}$ 1-1 individuals are at elevated risk for CHD mortality in a 10-year followup study [155]. They postulated that Hp 2-2 might play a role in early atherogenesis, but $\mathrm{Hp} \mathrm{1-1} \mathrm{has} \mathrm{a} \mathrm{predominant}$ influence in more advanced and life-threatening stages of the disease [155]. They also concluded that $\mathrm{Hp} \mathrm{1-1} \mathrm{is} \mathrm{of}$ greater prognostic importance for CHD death than classical risk factors, such as smoking, obesity, and diabetes [155].

\subsection{Ceruloplasmin}

2.8.1. Chemical Structure, Function, and Biological Activity. Ceruplasmin $(\mathrm{Cp})$ is a positive acute phase reactant with bactericidal activity [156]. $\mathrm{Cp}$ is a $132-\mathrm{kDa}$ monomer composed entirely of three $42-45-\mathrm{kDa}$ domains with high amino acid sequence homology (about 40\%) to each other [156]. Cp is an abundant plasma protein that contains seven copper atoms per molecule and accounts for 95\% of the total circulating copper in healthy adults $[157,158]$. The physiological function activities of $\mathrm{Cp}$ include copper transport, coagulation, angiogenesis, defense against oxidant stress, and iron homeostasis [156]. The "ferroxidase" activity of $\mathrm{Cp}$ catalyzes oxidation of $\mathrm{Fe}^{2+}$ to $\mathrm{Fe}^{3+}$ [157] and is thought to facilitate in vitro loading of iron into the iron transport and storage proteins transferrin and ferritin [159].

2.8.2. Serum CP Predicts Cardiovascular Events. Tang et al. measured serum $\mathrm{Cp}$ levels in 3,569 consecutive stable patients undergoing elective coronary angiography with available leukocyte counts and hs-CRP levels [160]. The role of $\mathrm{Cp}$ in predicting incident major adverse cardiac events over 3 years of followup was evaluated [160]. A strong positive correlation with hsCRP was observed [160]. Cp level (Quartiles 4 versus 1) was associated with almost 3-fold increase in risk of future major adverse cardiovascular events at 1 year [160]. After adjusting for traditional risk factors including hsCRP, and total leukocyte count, Cp remained independently predictive of major adverse cardiovascular events at 1 year (HR 2.51, 95\% CI 1.40-4.49, $P=0.001$ ) and at 3 years (HR 1.48, 95\% CI 1.01-1.26) [160]. This study concluded that serum Cp independently predicts cardiovascular events.

Adelstein et al. and Bustamante et al. observed substantial hypercupremia after MI $[161,162]$. Since that report, high serum Cp levels were found in patients with multiple cardiovascular disorders including arteriosclerosis [163], abdominal aortic aneurysm [164], unstable angina [165], and vasculitis and peripheral arterial disease [166]. Prospective studies also showed that serum Cp may be an independent risk factor for cardiovascular disease [162]. A prospective Finnish study verified that serum copper concentration was an independent risk factor for ischemic heart disease [167]. The association between $\mathrm{Cp}$ and cardiovascular events is well explained by describing a role for Cp in LDL oxidation by vascular cells (free radical-mediated, transition metaldependent mechanism) [156]. A model for LDL oxidation by $\mathrm{Cp}$ in an atherosclerotic lesion was described that shows that $\mathrm{Cp}$ is synthesized by macrophages which are activated by TNF-a (proinflammatory cytokine) or by bacterial lipopolysaccharide (cell wall product of infectious organism) [156]. This secreted Cp [168] along with redox-active copper [169], are required for vascular cell-mediated LDL oxidation.

2.8.3. Prognostic Value of Serum Cp. Prognostic value of serum Cp has been compared against that of CRP and fibrinogen in 40 patients of unstable angina over 12 months period [170]. All acute phase proteins were measured in the total study group and in the subgroup with normal troponin T [170]. The levels of serum Cp were found elevated when compared against those in stable angina patients [171]. Serum Cp increased significantly at 72 hours and reach peak levels at 7 days, both in the total study group and in the subgroup with normal troponin $\mathrm{T}$ [170]. On the other hand, CRP and fibrinogen serum levels elevated way earlier than those of Cp and last to a way shorter period [170]. All values of acute phase proteins were similar during the in-hospital course [170]. However, CP but not CRP and fibrinogen levels showed a prognostic value because they were significantly higher in patients with complications in both groups, and logistic regression analysis showed that $\mathrm{CP}$ levels at 72 hours were the most important factor related to 12-month prognosis [170].

The role of serum copper in a 2-year progression of atherosclerotic carotid lesions (measured by ultrasonography) in eastern Finnish men was examined by Salonen et al. [172]. An accelerated progression of atherosclerosis was seen only in patients with both high serum LDL and high serum copper [172]. They thought that the prooxidant activity of the copper may be due to a synergism of copper and LDL [173]. Mezzetti et al. also examined the importance of serum CP and LDL oxidation in lesion development in patients undergoing endarterectomy for internal carotid stenosis [174]. They reported that serum CP and LDL lipid peroxide levels measured 24 or 72 hours after surgery were highly correlated with the percentage renarrowing measured after 12 months [174].

Taking together, these studies suggest that the contribution of CP to the risk of CVD is not independent but rather depends on the lipoprotein profile and possibly other factors [170].

\section{Negative Acute Phase Reactants}

3.1. Serum Albumin. Serum albumin is a negative acute phase protein synthesized in liver. Lower levels of serum albumin within the "normal" range are associated with increased risk of all-cause and cardiovascular mortality [175], as well as with coronary heart disease (CHD) [176, 177] and stroke incidence [178]. These associations persist after adjustment for other known risk factors and preexisting disease and after exclusion of early mortality $[175,177]$.

3.1.1. Chemistry and Biological Activity. Serum albumin level accounts for about $50-60 \%$ of the serum proteins with 
a range of $35-50 \mathrm{~g} / \mathrm{L}[179,180]$. Human serum albumin (HSA), a protein of molecular weight $65 \mathrm{KDa}$, consists of 585 amino acids and one free thiol (Cys 34). The disulphides are positioned in a repeating series of nine loop-link-loop structures centered around eight sequential Cys-Cys pairs to form heart-shaped [179]. Plasma proteins have been suggested as the major extracellular antioxidants in extracellular fluid [179]. Among them, albumin, transferrin, and ceruloplasmin, can sequester transition metals, preventing them from acting as catalysts in highly reactive biochemical reactions [179]. Several studies have suggested that albumin as a powerful oxidants scavenger in human plasma can inhibit hydroxyl radicals, peroxyl radicals, and $\mathrm{HOCl}[179$, 181].

\subsubsection{Serum Albumin-Cardiovascular Disease Association.} Substantial evidence support the significant inverse relation between serum albumin level and risk of coronary heart disease as well as cancer, other causes of death, and all-cause mortality [182-184]. Høstmark [185] reported that albumin as an extracellular antioxidant does have a cardioprotective role against lipid peroxidation [185].

In patients with renal failure, there is a pathophysiological link between CVD, malnutrition, inflammation [186] and serum levels of CRP [187-189]. Additionally, a low level of serum albumin is also a strong predictor of morbidity and mortality in patients with kidney failure [190192]. Hypoalbuminemia of kidney failure, in part, may be a consequence of activation of the acute phase response and may represent a chronic inflammatory state [193-195]. Kim et al. suggested possible mechanisms that might link hypoalbuminemia with CVD [196].

(1) Cause-Effect Association:

(i) Albumin, Atherogenic Lipids and Lipoproteins Association. A significant inverse relationship between serum albumin and lipoprotein (a) has been reported in patients with nephrotic syndrome [197] and in dialysis patients [198, 199]. Stenvinkel et al. showed that an elevated rate of LDLApo B production is highly correlated to the prevailing serum albumin levels in patients with nephrotic syndrome [200]. It was shown that by increasing serum albumin levels in continuous ambulatory peritoneal dialysis patients, serum lipoprotein (a) levels were decreased [201]. These findings have been confirmed these findings in humans and rats [202, 203].

(ii) Albumin-Fibrinogen Association. Fibrinogen levels correlate inversely with serum albumin levels in patients with nephrotic syndrome [204] and in continuous ambulatory peritoneal dialysis patients [205]. Pickart and Thaler. showed that addition of albumin abolished the free fatty-acidassociated increase in fibrinogen synthesis in mouse liver slices [206]. The intravenous infusion of albumin solution to seriously injured patients caused a significant fall in fibrinogen concentration [207]. Kim et al. suggested that hypoalbuminemia increases plasma fibrinogen levels [208].

(iii) Albumin and Platelet Aggregation. There are several reports that platelet aggregation in patients with nephrotic syndrome and in patients on continuous ambulatory peritoneal dialysis, were inversely proportional to the serum albumin concentration [209-211]. Several investigators reported that the addition of albumin in vivo [212] or in vitro $[210,213,214]$ corrected this defect. Schieppati et al. showed that the addition of albumin to plateletrich plasma from patients with nephrotic syndrome, or the intravenous infusion of albumin in quantities sufficient to correct hypoalbuminemia, also diminished the excessive production of prostaglandin metabolites by nephrotic platelets [215]. Albumin is a lipooxygenase inhibitor in serum [216], which suggests that hypoalbuminemia increases synthesis of leukotrienes [196].

(iv) Albumin and Blood Viscosity. Groth demonstrated that infusion of albumin or dextran 40 in 14 patients with various diseases decreased blood and plasma viscosity [217]. Elevated plasma and whole blood viscosity has been reported in patients with nephrotic syndrome [218]. Joles et al. reported that albumin deficiency is accompanied by blood hyperviscosity, possibly by increasing red cell lysophosphatidylcholine [219]. Continuous ambulatory peritoneal dialysis patients had higher whole-blood viscosity than control subjects when all samples were reconstituted to $70 \%$ hematocrit [220]. Plasma viscosity was also higher in continuous ambulatory peritoneal dialysis patients than in hemodialysis patients and controls [220]. In the study of Gordge et al., plasma viscosity correlated significantly with the degree of proteinuria in 21 diabetic patients with renal failure [221].

(2) Effect-Effect Association. Serum albumin was negatively correlated with C-reactive protein (CRP) $[222,223]$. However, infusion of albumin in patients with hypoalbuminemia did not have an effect on the level of CRP [205]. These findings suggest that the correlation between albumin and CRP may be secondary to inflammation rather than a direct effect of hypoalbuminemia. As well, diabetes and cigarette smoking can cause hypoalbuminemia and atherosclerosis despite the fact that they are not major determinants of hypoalbuminemia in dialysis patients [224].

\subsection{Transthyretin}

3.2.1. Chemistry and Biological Activity. Transthyretin (TTR) was formerly called prealbumin (since it migrates closer to the anode compared to albumin on serum protein electrophoresis), but this term is misleading as TTR is not a precursor of albumin [225]. TTR is a globular, nonglycosylated protein with a molecular mass of $54.98 \mathrm{kDa}$ [226]. The total mass is approximately $76 \mathrm{kDa}$ with a complexed molecule of retinol-binding protein (RBP; $21 \mathrm{kDa}$ ) [227], which is still small enough to diffuse out of the vascular space as readily as albumin $(66.3 \mathrm{kDa})$ or transferrin $(79.6 \mathrm{kDa})$; slightly less than $50 \%$ of each of these proteins is normally intravascular as a result [228]. TTR is a negative acute phase protein synthesized primarily in the liver, except for tiny amounts produced by the choroid plexus and the retina $[225,229]$. In serum, TTR transports thyroxine and retinol (along with RBP) [230]. The TTR protein circulates as a homotetramer, in which each monomer comprises 127 amino acids arranged as eight antiparallel $\beta$ pleated sheet domains [231]. The TTR gene is located on chromosome 18 
and contains four exons [225]. Both wild type and mutated TTR can form amyloid, which suggests that this highly structured protein is innately prone to form $\beta$-pleated sheet fibrils [232, 233]. Alterations in the primary structure of the TTR protein (owing to TTR mutations) can result in greatly accelerated amyloid formation and are the origin of all symptomatic cases of hereditary transthyretin-related amyloidosis (ATTR) [234] which can consequently cause organ dysfunction [225].

\subsubsection{Common Associated-TTR Amyloidoses with Emphasis} on CV Manifestations. TTR is associated with two distinct forms of cardiac amyloidoses: hereditary transthyretinrelated amyloidosis (ATTR) which is caused by mutations in the TTR gene, which encodes TTR $[225,235]$, whereas systemic senile amyloidosis (SSA) is not inherited and is associated with wild type TTR [235]. In patients with ATTR, amyloid can infiltrate any or all of the cardiovascular structures, including the conduction system, the atrial and ventricular myocardium, valvular tissue, and the coronary and large arteries $[236,237]$. Branch bundle block leading to atrioventricular and sinoatrial block are the fate of the conduction system compromise [225]. Myocardial infiltration results in a progressive increase in the thickness of the left and right ventricular walls and of the interatrial septum and is associated with worsening hemodynamic impairment [225]. In a study of 38 patients with ATTR-related cardiomyopathy, only one patient $(3 \%)$ showed a dip plateau in the right ventricular pressure curve profile; 13 patients (34\%) showed raised pulmonary capillary wedge pressures, and 14 (47\%) showed a Doppler restrictive filling pattern. Interestingly, $11(29 \%)$ of the patients did not display any abnormalities in diastolic function-at least when at rest [238]. LVEF is generally normal or only mildly reduced in patients with ATTR cardiomyopathy [239]. Amyloid infiltration of cardiac valves leads to the formation of nodules or diffuse thickening of the leaflets, accompanied by variable degrees (generally mild) of valvular regurgitation [225]. The clinical spectrum of cardiovascular involvement is wide, ranging from asymptomatic atrioventricular and bundle branch block to severe, rapidly progressive heart failure owing to restrictive cardiomyopathy [225].

3.2.3. Diagnosis. Diagnosis of systemic amyloidosis is based on monoclonal gammopathy by immunoelectrophoresis, immunofixation on serum and urine, or mutant transthyretin gene as potential risk factors for amyloid disease, and confirmed by positive Congo red staining of any biopsy (periumbilical fat aspiration, rectum, target organ) [240].

\subsubsection{Transthyretin as a Therapeutic Target}

Fibril Disrupters. Recently, 4'-deoxy-4'-iododoxorubicin (IDOX) has been proved useful as a tool for disrupting TTR amyloid fibrils [173]. The amyloid disrupters might also prove useful for amyloidoses associated with other protein precursors, such as the $\mathrm{L}$ protein in Alzheimer and the prion scrapie protein [173]. Due to its cardiotoxicity, IDOX analogues able to disrupt amyloid fibrils are needed [173].

TTR Stabilizers. Diclofenac is a good example for TTR stabilizers. Diclofenac is an NSAID approved by FDA [241]. TTR-diclofenac complex revealed that the ring with the acetate function is positioned at the innermost part of the binding site, allowing strong hydrogen bond interaction between the drug $\mathrm{COOH}$ group and the side chain of Thr119 [241]. In this case the two phenyl rings and the chlorine atoms provide extensive van der Waals interactions with the protein residues that form the $\mathrm{P} 1$ and $\mathrm{P} 3$ pockets [241]. Diflunisal, which is another nonsteroidal NSAID, has been found to stabilize the tetrameric structure of TTR [242], that is, reduces tetramer dissociation and subsequent monomer misfolding and aggregation into amyloid [236, 242].

3.2.5. Laboratory Assays for TTR. The methods most commonly used at present are immunonephelometry (IN) and immunoturbidimetry (IT) [243]. Preanalytical factors may also influence plasma concentrations of proteins and other macromolecules [243]. Of particular importance is body position; individuals who have been standing or recumbent for long periods of time have higher or lower concentrations, respectively [243]. It is generally recommended that blood specimens for assay of plasma proteins be drawn after approximately $15-20 \mathrm{~min}$ in the sitting position if possible [243].

\subsection{Serum Transferrin}

3.3.1. Chemistry and Biological Activity. The transferrin family (Trf) constitutes the major iron transport and/or scavenging system in vertebrates and some invertebrates [244]. However, $\operatorname{Trf}$ can also function as an iron chelator, which contributes to host defense by limiting iron availability for microbial pathogens [244]. Trf is a negative acute phase reactant. Trf is a soluble glycoprotein and a bilobal molecule, that is, it contains an $\mathrm{N}$-terminal (amino acids 1-336) and a C- terminal (amino acids 337-679) globular domain [245]. Each domain contains a metal-binding site and each lobe binds one iron atom [245]. Amino acid sequences of Trf from several species, including human, bovine, rabbit, and chicken, show a high degree of sequence similarity [246]. Under normal conditions, these two high-affinity-iron binding sites prevent the existence of measurable amounts of unbound iron in the plasma [245]. The main source of iron for Trf is catabolism of nonviable red blood cells and its main destination is the erythroid marrow [245]. Serum Trf transport iron from neutral biological fluids to the cytoplasm by receptor-mediated endocytosis [247]. Free iron is capable of stimulating the production of free radicals which cause oxidative damage such as lipid peroxidation [245].

3.3.2. Transferrin-Cardiovascular Disease Association. Trf is one of the most important antioxidants and acts by sequestration of iron in a redox-inactive form [248]. Apotransferrin, at physiological concentrations $(2-3 \mathrm{mg} / \mathrm{mL})$ is 
known to inhibit lipid peroxidation in the liposome model by iron-binding [248]. However, at higher concentrations, apotransferrin does not inhibit lipid peroxidation any further, while at low concentrations, apotransferrin reduces antioxidant capacity in a concentration-dependent manner [248]. This finding was clinically relevant in diseases that are associated with lower plasma transferrin concentrations as a result of either a decreased synthesis or increased breakdown such as type 1 and type 2 diabetes mellitus [248]. It has been shown that oxidative damage to transferrin by neutrophil-derived superoxide increases ferrous iron release [249]. In vitro glycation of hemoglobin also results in a higher release of iron. Purified hemoglobin from diabetic patients compared to normal individuals contains more free iron, which increases progressively with the extent of the disease [250]. As $\operatorname{Trf}$ is a negative acute phase protein, it is downregulated in inflammatory diseases such as diabetes [248]. Moreover, oxidative damage results in protein fragmentation and nephropathy which can lead to loss of transferrin in the urine of type 1 and type 2 diabetic patients [248]. Interestingly, microtransferrinuria seems to be a more sensitive index for renal dysfunction than microalbuminuria [248, 251-255]. The low concentration of transferrin often found in the disease also appears to reflect the increased iron stores, and the concentration returns to normal after iron-depletion therapy. It seems unlikely that hemochromatosis is related to a primary defect in transferrin [256]. Cartei et al. demonstrated that venesection therapy causes the rise of plasma transferrin due to the removal of iron overload and not to venesection per se [256]. Another possible defect in hemochromatosis is the decreased ability of reticuloendothelial cells to retain iron [257]. The result of this defect is a return of greater amounts of iron from stores to plasma ferritin, increasing its iron saturation and thus causing more iron saturation and directing more iron into hepatocyte storage [256]. Batey et al. have confirmed the existence of a nontransferrin-bound iron (NTBI) fraction in the sera of patients with untreated or inadequately treated primary hemochromatosis which may, in part explain the findings in primary hemochromatosis [257].

\section{Conclusion}

The presence and intensity of inflammation of cardiovascular disorders can be reflected by acute phase changes. Acute phase responses have long been used as a clinical guide to diagnosis, management, and prognosis. Not only this, but also they can be used to predict a new-onset cardiovascular disorder.

\section{References}

[1] W. S. Tillett and T. Francis, "Serological reactions in pneumonia with a non-protein somatic fraction of pneumococcus," The Journal of Experimental Medicine, vol. 52, pp. 561-567, 1930.

[2] A. S. Whitehead, G. A. P. Bruns, and A. F. Markham, "Isolation of human C-reactive protein complementary DNA and localization of the gene to chromosome 1," Science, vol. 221, no. 4605 , pp. 69-71, 1983.
[3] E. B. Oliveira, E. C. Gotschlich, and T. Y. Liu, "Primary structure of human C-reactive protein," The Journal of Biological Chemistry, vol. 254, no. 2, pp. 489-502, 1979.

[4] P. A. Kavsak, A. R. MacRae, A. M. Newman et al., "Elevated C-reactive protein in acute coronary syndrome presentation is an independent predictor of long-term mortality and heart failure," Clinical Biochemistry, vol. 40, no. 5-6, pp. 326-329, 2007.

[5] M. B. Pepys and G. M. Hirschfield, "C-reactive protein: a critical update," Journal of Clinical Investigation, vol. 111, no. 12, pp. 1805-1812, 2003.

[6] D. M. Vigushin, M. B. Pepys, and P. N. Hawkins, "Metabolic and scintigraphic studies of radioiodinated human Creactive protein in health and disease," Journal of Clinical Investigation, vol. 91, no. 4, pp. 1351-1357, 1993.

[7] H. Yu and N. Rifai, "High-sensitivity C-reactive protein and atherosclerosis: from theory to therapy," Clinical Biochemistry, vol. 33, no. 8, pp. 601-610, 2000.

[8] R. Ross, "Atherosclerosis-an inflammatory disease," The New England Journal of Medicine, vol. 340, no. 2, pp. 115126, 1999.

[9] T. P. Zwaka, V. Hombach, and J. Torzewski, "C-reactive protein-mediated low density lipoprotein uptake by macrophages: implications for atherosclerosis," Circulation, vol. 103, no. 9, pp. 1194-1197, 2001.

[10] V. Pasceri, J. Chang, J. T. Willerson, and E. T. H. Yeh, "Modulation of C-reactive protein-mediated monocyte chemoattractant protein-1 induction in human endothelial cells by anti-atherosclerosis drugs," Circulation, vol. 103, no. 21, pp. 2531-2534, 2001.

[11] K. Yasojima, C. Schwab, E. G. McGeer, and P. L. McGeer, "Generation of C-reactive protein and complement components in atherosclerotic plaques," American Journal of Pathology, vol. 158, no. 3, pp. 1039-1051, 2001.

[12] B. C. Berk, W. S. Weintraub, and R. W. Alexander, "Elevation of C-reactive protein in "active" coronary artery disease," American Journal of Cardiology, vol. 65, no. 3, pp. 168-172, 1990.

[13] E. Braunwald, "Unstable angina: an etiologic approach to management," Circulation, vol. 98, no. 21, pp. 2219-2222, 1998.

[14] M. Cesari, B. W. J. H. Penninx, A. B. Newman et al., "Inflammatory markers and onset of cardiovascular events: results from the health ABC study," Circulation, vol. 108, no. 19, pp. 2317-2322, 2003.

[15] G. J. Blake and P. M. Ridker, "C-reactive protein and other inflammatory risk markers in acute coronary syndromes," Journal of the American College of Cardiology, vol. 41, no. 4, supplement, pp. 37S-42S, 2003.

[16] C. Heeschen, C. W. Hamm, J. Bruemmer, and M. L. Simoons, "Predictive value of C-reactive protein and troponin $\mathrm{T}$ in patients with unstable angina: a comparative analysis," Journal of the American College of Cardiology, vol. 35, no. 6, pp. 1535-1542, 2000.

[17] F. C. De Beer, C. R K Hind, K. M. Fox, R. M. Allan, A. Maseri, and M. B. Pepys, "Measurement of serum Creactive protein concentration in myocardial ischaemia and infarction," British Heart Journal, vol. 47, no. 3, pp. 239-243, 1982.

[18] K. Pietilä, A. Harmoinen, L. Pöyhönen, M. Koskinen, J. Heikkila, and R. Ruosteenoja, "Intravenous streptokinase treatment and serum C-reactive protein in patients with acute myocardial infarction," British Heart Journal, vol. 58, no. 3, pp. 225-229, 1987. 
[19] S. Ueda, U. Ikeda, and K. Yamamoto, "C-reactive protein and complement in myocardial infarction and postinfarction heart failure," European Heart Journal, vol. 18, no. 11, pp. 1834-1837, 1997.

[20] T. Anzai, T. Yoshikawa, H. Shiraki et al., "C-reactive protein as a predictor of infarct expansion and cardiac rupture after a first Q-wave acute myocardial infarction," Circulation, vol. 96, no. 3, pp. 778-784, 1997.

[21] H. Toss, B. Lindahl, A. Siegbahn, and L. Wallentin, "Prognostic influence of increased fibrinogen and C-reactive protein levels in unstable coronary artery disease," Circulation, vol. 96, no. 12, pp. 4204-4210, 1997.

[22] S. K. James, P. Armstrong, E. Barnathan et al., "Troponin and $\mathrm{C}$-reactive protein have different relations to subsequent mortality and myocardial infarction after acute coronary syndrome: a. GUSTO-IV Substudy," Journal of the American College of Cardiology, vol. 41, no. 6, pp. 916-924, 2003.

[23] B. Lindahl, H. Toss, A. Siegbahn, P. Venge, and L. Wallentin, "Markers of myocardial damage and inflammation in relation to long-term mortality in unstable coronary artery disease," The New England Journal of Medicine, vol. 343, no. 16, pp. 1139-1147, 2000.

[24] S. K. James, B. Lindahl, A. Siegbahn et al., "N-terminal pro-brain natriuretic peptide and other risk markers for the separate prediction of mortality and subsequent myocardial infarction in patients with unstable coronary artery disease: a global utilization of strategies to open occluded arteries (GUSTO)-IV substudy," Circulation, vol. 108, no. 3, pp. 275281, 2003.

[25] M. Suleiman, R. Khatib, Y. Agmon et al., "Early inflammation and risk of long-term development of heart failure and mortality in survivors of acute myocardial infarction: predictive role of C-reactive protein," Journal of the American College of Cardiology, vol. 47, no. 5, pp. 962-968, 2006.

[26] C. Mueller, H. J. Buettner, J. M. Hodgson et al., "Inflammation and long-term mortality after non-ST elevation acute coronary syndrome treated with a very early invasive strategy in 1042 consecutive patients," Circulation, vol. 105, no. 12, pp. 1412-1415, 2002.

[27] P. M. Ridker, "Clinical application of C-reactive protein for cardiovascular disease detection and prevention," Circulation, vol. 107, no. 3, pp. 363-369, 2003.

[28] M. B. Pepys, "C-reactive protein fifty years on," The Lancet, vol. 1, no. 8221, pp. 653-657, 1981.

[29] P. M. Ridker, "High-sensitivity C-reactive protein and cardiovascular risk: rationale for screening and primary prevention," The American journal of cardiology, vol. 92, no. 4 B, 2003.

[30] R. S. Schwartz, A. Bayes-Genis, J. R. Lesser, M. Sangiorgi, T. D. Henry, and C. A. Conover, "Detecting vulnerable plaque using peripheral blood: inflammatory and cellular markers," Journal of Interventional Cardiology, vol. 16, no. 3, pp. 231242, 2003.

[31] E. M. Balk, J. Lau, L. C. Goudas et al., "Effects of statins on nonlipid serum markers associated with cardiovascular disease: a systematic review," Annals of Internal Medicine, vol. 139, no. 8, pp. 670-682, 2003.

[32] T. A. Pearson, G. A. Mensah, R. W. Alexander et al., "Markers of inflammation and cardiovascular disease: application to clinical and public health practice: a statement for healthcare professionals from the centers for disease control and prevention and the American Heart Association," Circulation, vol. 107, no. 3, pp. 499-511, 2003.
[33] A. Festa, A. J. G. Hanley, R. P. Tracy, R. D’Agostino, and S. M. Haffner, "Inflammation in the prediabetic state is related to increased insulin resistance rather than decreased insulin secretion," Circulation, vol. 108, no. 15, pp. 1822-1830, 2003.

[34] T. B. Ledue, D. L. Weiner, J. D. Sipe, S. E. Poulin, M. F. Collins, and N. Rifai, "Analytical evaluation of particle-enhanced immunonephelometric assays for C-reactive protein, serum amyloid A and mannose-binding protein in human serum," Annals of Clinical Biochemistry, vol. 35, no. 6, pp. 745-753, 1998.

[35] T. B. Ledue and N. Rifai, "Preanalytic and analytic sources of variations in C-reactive protein measurement: implications for cardiovascular disease risk assessment," Clinical Chemistry, vol. 49, no. 8, pp. 1258-1271, 2003.

[36] P. M. Ridker, M. Cushman, M. J. Stampfer, R. P. Tracy, and C. H. Hennekens, "Inflammation, aspirin, and the risk of cardiovascular disease in apparently healthy men," The New England Journal of Medicine, vol. 336, no. 14, pp. 973-979, 1997.

[37] I. S. Ockene, C. E. Matthews, N. Rifai, P. M. Ridker, G. Reed, and E. Stanek, "Variability and classification accuracy of serial high-sensitivity C-reactive protein measurements in healthy adults," Clinical Chemistry, vol. 47, no. 3, pp. 444450, 2001.

[38] L. M. Biasucci, G. Liuzzo, R. L. Grillo et al., "Elevated levels of C-reactive protein at discharge in patients with unstable angina predict recurrent instability," Circulation, vol. 99, no. 7, pp. 855-860, 1999.

[39] I. Kushner, M. L. Broder, and D. Karp, "Control of the acute phase response. Serum C-reactive protein kinetics after acute myocardial infarction," Journal of Clinical Investigation, vol. 61, no. 2, pp. 235-242, 1978.

[40] K. O. Pietilä, A. P. Harmoinen, J. Jokiniitty, and A. I. Pasternack, "Serum C-reactive protein concentration in acute myocardial infarction and its relationship to mortality during 24 months of follow-up in patients under thrombolytic treatment," European Heart Journal, vol. 17, no. 9, pp. 13451349, 1996.

[41] V. B. Patel, M. A. Robbins, and E. J. Topol, "C-reactive protein: a "golden marker" for inflammation and coronary artery disease," Cleveland Clinic Journal of Medicine, vol. 68, no. 6, pp. 521-534, 2001.

[42] W. Koenig, M. Sund, M. Fröhlich et al., "C-reactive protein, a sensitive marker of inflammation, predicts future risk of coronary heart disease in initially healthy middle-aged men: results from the MONICA (monitoring trends and determinants in cardiovascular disease) Augsburg cohort study, 1984 to 1992," Circulation, vol. 99, no. 2, pp. 237-242, 1999.

[43] P. M. Ridker, C. H. Hennekens, J. E. Buring, and N. Rifai, "C-reactive protein and other markers of inflammation in the prediction of cardiovascular disease in women," The New England Journal of Medicine, vol. 342, no. 12, pp. 836-843, 2000.

[44] M. K. Rutter, J. B. Meigs, L. M. Sullivan, R. B. D’Agostino, and P. W. F. Wilson, "C-reactive protein, the metabolic syndrome, and prediction of cardiovascular events in the Framingham offspring study," Circulation, vol. 110, no. 4, pp. 380-385, 2004.

[45] P. W. F. Wilson, B. H. Nam, M. Pencina, R. B. D’Agostino, E. J. Benjamin, and C. J. O'Donnell, “C-reactive protein and risk of cardiovascular disease in men and women from the Framingham Heart Study," Archives of Internal Medicine, vol. 165, no. 21, pp. 2473-2478, 2005. 
[46] J. J. Li and C. H. Fang, "C-reactive protein is not only an inflammatory marker but also a direct cause of cardiovascular diseases," Medical Hypotheses, vol. 62, no. 4, pp. 499-506, 2004.

[47] L. J. Powell, "C-reactive protein-a review," The American journal of medical technology, vol. 45, no. 2, pp. 138-142, 1979.

[48] K. Matsushita, H. Yatsuya, K. Tamakoshi et al., "Highsensitivity C-reactive protein is quite low in Japanese men at high coronary risk," Circulation Journal, vol. 71, no. 6, pp. 820-825, 2007.

[49] M. Kosuge, T. Ebina, T. Ishikawa et al., "Serum amyloid A is a better predictor of clinical outcomes than C-reactive protein in non-ST-segment elevation acute coronary syndromes," Circulation Journal, vol. 71, no. 2, pp. 186-190, 2007.

[50] R. L. Meek, S. Urieli-Shoval, and E. P. Benditt, "Expression of apolipoprotein serum amyloid A mRNA in human atherosclerotic lesions and cultured vascular cells: implications for serum amyloid A function," Proceedings of the National Academy of Sciences of the United States of America, vol. 91, no. 8, pp. 3186-3190, 1994.

[51] V. L. King, J. Thompson, and L. R. Tannock, "Serum amyloid A in atherosclerosis," Current Opinion in Lipidology, vol. 22, no. 4, pp. 302-307, 2011.

[52] R. Badolato, J. M. Wang, W. J. Murphy et al., "Serum amyloid A is a chemoattractant: induction of migration, adhesion, and tissue infiltration of monocytes and polymorphonuclear leukocytes," Journal of Experimental Medicine, vol. 180, no. 1, pp. 203-209, 1994.

[53] R. O’Hara, E. P. Murphy, A. S. Whitehead, O. FitzGerald, and B. Bresnihan, "Local expression of the serum amyloid A and formyl peptide receptor-like 1 genes in synovial tissue is associated with matrix metalloproteinase production in patients with inflammatory arthritis," Arthritis and Rheumatism, vol. 50, no. 6, pp. 1788-1799, 2004.

[54] C. Song, Y. Shen, E. Yamen et al., "Serum amyloid A may potentiate prothrombotic and proinflammatory events in acute coronary syndromes," Atherosclerosis, vol. 202, no. 2, pp. 596-604, 2009.

[55] H. Cai, C. Song, I. Endoh et al., "Serum amyloid A induces monocyte tissue factor," Journal of Immunology, vol. 178, no. 3, pp. 1852-1860, 2007.

[56] C. P. J. Maury, "Comparative study of serum amyloid A protein and C-reactive protein in disease," Clinical Science, vol. 68, no. 2, pp. 233-238, 1985.

[57] J. Wilkins, J. R. Gallimore, G. A. Tennent et al., "Rapid automated enzyme immunoassay of serum amyloid A," Clinical Chemistry, vol. 40, no. 7, pp. 1284-1290, 1994.

[58] T. Nakayama, S. Sonoda, T. Urano, T. Yamada, and M. Okada, "Monitoring both serum amyloid protein A and C-reactive protein as inflammatory markers in infectious diseases," Clinical Chemistry, vol. 39, no. 2, pp. 293-297, 1993.

[59] J. M. Mayer, M. Raraty, J. Slavin et al., "Serum amyloid A is a better early predictor of severity than C-reactive protein in acute pancreatitis," British Journal of Surgery, vol. 89, no. 2, pp. 163-171, 2002.

[60] G. Cunnane, S. Grehan, S. Geoghegan et al., "Serum amyloid A in the assessment of early inflammatory arthritis," Journal of Rheumatology, vol. 27, no. 1, pp. 58-63, 2000.

[61] M. T. Casl, G. Bulatovic, P. Orlic, and M. SabljarMatovinovic, "The diagnostic capacity of serum amyloid A protein for early recognition of kidney allograft rejection," Nephrology Dialysis Transplantation, vol. 10, no. 10, pp. 1901-1904, 1995.
[62] T. Katayama, H. Nakashima, C. Takagi et al., "Prognostic value of serum amyloid a protein in patients with acute myocardial infarction," Circulation Journal, vol. 69, no. 10, pp. 1186-1191, 2005.

[63] G. Liuzzo, L. M. Biasucci, J. R. Gallimore et al., "The prognostic value of C-reactive protein and serum amyloid A protein in severe unstable angina," The New England Journal of Medicine, vol. 331, no. 7, pp. 417-424, 1994.

[64] T. W. Meade, W. R. North, R. Chakrabarti et al., "Haemostatic function and cardiovascular death: early results of a prospective study," The Lancet, vol. 1, no. 8177, pp. 10501053, 1980.

[65] W. Nieuwenhuizen, "Biochemistry and measurement of fibrinogen," European Heart Journal, vol. 16, supplement, pp. 6-10, 1995.

[66] R. F. Doolittle, "Fibrinogen and fibrin," Scientific American, vol. 245, no. 6, pp. 126-152, 1981.

[67] J. J. Stec, H. Silbershatz, G. H. Tofler et al., "Association of fibrinogen with cardiovascular risk factors and cardiovascluar disease the Framingham Offspring Population," Circulation, vol. 102, no. 14, pp. 1634-1638, 2000.

[68] M. J. Davies, "The contribution of thrombosis to the clinical expression of coronary atherosclerosis," Thrombosis Research, vol. 82, no. 1, pp. 1-32, 1996.

[69] M. Eriksson, N. Egberg, S. Wamala, K. Orth-Gomér, M. A. Mittleman, and K. Schenck-Gustafsson, "Relationship between plasma fibrinogen and coronary heart disease in women," Arteriosclerosis, Thrombosis, and Vascular Biology, vol. 19, no. 1, pp. 67-72, 1999.

[70] S. G. Thompson, J. Kienast, S. D. M. Pyke et al., "Hemostatic factors and the risk of myocardial infarction or sudden death in patients with angina pectoris," The New England Journal of Medicine, vol. 332, no. 10, pp. 635-641, 1995.

[71] R. Fogari, A. Zoppi, G. Marasi, A. Vanasia, and G. Villa, "Associations between plasma fibrinogen levels and cardiovascular risk factors in hypertensive men," Journal of Cardiovascular Risk, vol. 1, no. 4, pp. 341-345, 1994.

[72] H. H. Ditschuneit, M. Flechtner-Mors, and G. Adler, "Fibrinogen in obesity before and after weight reduction," Obesity Research, vol. 3, no. 1, pp. 43-48, 1995.

[73] J. Heinrich, L. Balleisen, H. Schulte, G. Assmann, and J. Van de Loo, "Fibrinogen and factor VII in the prediction of coronary risk: results from the PROCAM study in healthy men," Arteriosclerosis and Thrombosis, vol. 14, no. 1, pp. 5459, 1994.

[74] E. Vanninen, J. Laitinen, and M. Uusitupa, "Physical activity and fibrinogen concentration in newly diagnosed NIDDM," Diabetes Care, vol. 17, no. 9, pp. 1031-1038, 1994.

[75] M. Gil, M. Zarebiński, and J. Adamus, "Plasma fibrinogen and troponin I in acute coronary syndrome and stable angina," International Journal of Cardiology, vol. 83, no. 1, pp. 43-46, 2002.

[76] Y. Shi, Y. Wu, C. Bian, W. Zhang, J. Yang, and G. Xu, "Predictive value of plasma fibrinogen levels: in patients admitted for acute coronary syndrome," Texas Heart Institute Journal, vol. 37, no. 2, pp. 178-183, 2010.

[77] J. S. Rana, S. M. Boekholdt, P. M. Ridker et al., "Differential leucocyte count and the risk of future coronary artery disease in healthy men and women: the EPIC-Norfolk Prospective Population Study," Journal of Internal Medicine, vol. 262, no. 6, pp. 678-689, 2007.

[78] C. S. Keefer and W. H. Resnik, "Angina pectoris: a syndrome caused by anoxemia of the myocardium," Archives of Internal Medicine, vol. 41, pp. 769-807, 1928. 
[79] J. B. Zalokar, J. L. Richard, and J. R. Claude, "Leukocyte count, smoking, and myocardial infarction," The New England Journal of Medicine, vol. 304, no. 8, pp. 465-468, 1981.

[80] R. H. Grimm Jr., J. D. Neaton, and W. Ludwig, "Prognostic importance of the white blood cell count for coronary, cancer, and all-cause mortality," Journal of the American Medical Association, vol. 254, no. 14, pp. 1932-1937, 1985.

[81] A. N. Phillips, J. D. Neaton, D. G. Cook, R. H. Grimm, and A. G. Shaper, "Leukocyte count and risk of major coronary heart disease events," American Journal of Epidemiology, vol. 136, no. 1, pp. 59-70, 1992.

[82] W. B. Kannel, K. Anderson, and P. W. F. Wilson, "White blood cell count and cardiovascular disease: insights from the Framingham study," Journal of the American Medical Association, vol. 267, no. 9, pp. 1253-1256, 1992.

[83] R. F. Gillum, D. D. Ingram, and D. M. Makuc, "White blood cell count, coronary heart disease, and death: the NHANES I epidemiologic follow-up study," American Heart Journal, vol. 125, no. 3, pp. 855-863, 1993.

[84] A. R. Folsom, K. K. Wu, W. D. Rosamond, A. R. Sharrett, and L. E. Chambless, "Prospective study of hemostatic factors and incidence of coronary heart disease: the Atherosclerosis Risk in Communities (ARIC) Study," Circulation, vol. 96, no. 4, pp. 1102-1108, 1997.

[85] C. D. Lee, A. R. Folsom, F. J. Nieto, L. E. Chambless, E. Shahar, and D. A. Wolfe, "White blood cell count and incidence of coronary heart disease and ischemic stroke and mortality from cardiovascular disease in African-American and White men and women: atherosclerosis Risk in Communities Study," American Journal of Epidemiology, vol. 154, no. 8, pp. 758-764, 2001.

[86] D. W. Brown, W. H. Giles, and J. B. Croft, "White blood cell count: an independent predictor of coronary heart disease mortality among a national cohort," Journal of Clinical Epidemiology, vol. 54, no. 3, pp. 316-322, 2001.

[87] M. Madjid, I. Awan, J. T. Willerson, and S. W. Casscells, "Leukocyte count and coronary heart disease: implications for risk assessment," Journal of the American College of Cardiology, vol. 44, no. 10, pp. 1945-1956, 2004.

[88] R. C. Schlant, S. Forman, J. Stamler, and P. L. Canner, "The natural history of coronary heart disease: prognostic factors after recovery from myocardial infarction in 2789 men. The 5 -year findings of the coronary drug project," Circulation, vol. 66, no. 2, pp. 401-414, 1982.

[89] R. Hajj-Ali, W. Zareba, R. Ezzeddine, and A. J. Moss, "Relation of the leukocyte count to recurrent cardiac events in stable patients after acute myocardial infarction," American Journal of Cardiology, vol. 88, no. 11, pp. 1221-1224, 2001.

[90] G. Schillaci, M. Pirro, G. Pucci et al., "Prognostic value of elevated white blood cell count in hypertension," American Journal of Hypertension, vol. 20, no. 4, pp. 364-369, 2007.

[91] R. H. Orakzai, S. H. Orakzai, K. Nasir et al., "Association of white blood cell count with systolic blood pressure within the normotensive range," Journal of Human Hypertension, vol. 20, no. 5, pp. 341-347, 2006.

[92] G. D. Friedman, J. V. Selby, and C. P. Quesenberry Jr., "The leukocyte count: a predictor of hypertension," Journal of Clinical Epidemiology, vol. 43, no. 9, pp. 907-911, 1990.

[93] O. Kuchel, "The autonomic nervous system and blood pressure regulation in human hypertension," in Hypertension: Physiopathology and Treatment, J. Genest, O. Kuchal, P. Hamet, and M. Cantin, Eds., pp. 140-160, McGraw- Hill, New York, NY, USA, 2nd edition, 1983.
[94] S. Umemoto, N. Suzuki, K. Fujii et al., "Eosinophil counts and plasma fibrinogen in patients with vasospastic angina pectoris," American Journal of Cardiology, vol. 85, no. 6, pp. 715-719, 2000.

[95] L. M. Biasucci, G. D’Onofrio, G. Liuzzo et al., "Intracellular neutrophil myeloperoxidase is reduced in unstable angina and acute myocardial infarction, but its reduction is not related to ischemia," Journal of the American College of Cardiology, vol. 27, no. 3, pp. 611-616, 1996.

[96] S. Pontremoli, F. Salamino, B. Sparatore et al., "Enhanced activation of the respiratory burst oxidase in neutrophils from hypertensive patients," Biochemical and Biophysical Research Communications, vol. 158, no. 3, pp. 966-972, 1989.

[97] P. S. Tsao, X. L. Ma, and A. M. Lefer, "Activated neutrophils aggravate endothelial dysfunction after reperfusion of the ischemic feline myocardium," American Heart Journal, vol. 123, no. 6, pp. 1464-1471, 1992.

[98] T. Siminiak, N. A. Flores, and D. J. Sheridan, "Neutrophil interactions with endothelium and platelets: possible role in the development of cardiovascular injury," European Heart Journal, vol. 16, no. 2, pp. 160-170, 1995.

[99] E. H. Ohlstein and A. J. Nichols, "Rabbit polymorphonuclear neutrophils elicit endothelium-dependent contraction in vascular smooth muscle," Circulation Research, vol. 65, no. 4, pp. 917-924, 1989.

[100] A. R. Whorton, M. E. Montgomery, and R. S. Kent, "Effect of hydrogen peroxide on prostaglandin production and cellular integrity in cultured porcine aortic endothelial cells," Journal of Clinical Investigation, vol. 76, no. 1, pp. 295-302, 1985.

[101] Z. S. Katusic and P. M. Vanhoutte, "Superoxide anion is an endothelium-derived contracting factor," American Journal of Physiology, vol. 257, no. 1, pp. H33-H37, 1989.

[102] A. D. Hingorani, J. Cross, R. K. Kharbanda et al., "Acute systemic inflammation impairs endothelium-dependent dilatation in humans," Circulation, vol. 102, no. 9, pp. 994-999, 2000.

[103] J. Mehta, J. Dinerman, P. Mehta et al., "Neutrophil function in ishemic heart disease," Circulation, vol. 79, no. 3, pp. 549$556,1989$.

[104] I. Ott, F. J. Neumann, M. Gawaz, M. Schmitt, and A. Schömig, "Increased neutrophil-platelet adhesion in patients with unstable angina," Circulation, vol. 94, no. 6, pp. 12391246, 1996.

[105] S. R. Ommen, R. J. Gibbons, D. O. Hodge, and S. P. Thomson, "Usefulness of the lymphocyte concentration as a prognostic marker in coronary artery disease," American Journal of Cardiology, vol. 79, no. 6, pp. 812-814, 1997.

[106] S. Fichtlscherer, M. Kaszkin, S. Breuer, S. Dimmeler, and A. M. Zeiher, "Elevated secretory non-pancreatic type II phospholipase A2 serum activity is associated with impaired endothelial vasodilator function in patients with coronary artery disease," Clinical Science, vol. 106, no. 5, pp. 511-517, 2004.

[107] E. Hurt-Camejo, G. Camejo, H. Peilot, K. Öörni, and P. Kovanen, "Phospholipase A2 in vascular disease," Circulation Research, vol. 89, no. 4, pp. 298-304, 2001.

[108] H. W. M. Niessen, P. A. J. Krijnen, C. A. Visser, C. J. L. M. Meijer, and C. E. Hack, "Type II secretory phospholipase A2 in cardiovascular disease: a mediator in atherosclerosis and ischemic damage to cardiomyocytes?" Cardiovascular Research, vol. 60, no. 1, pp. 68-77, 2003.

[109] M. Menschikowski, A. Rosner-Schiering, R. Eckey, E. Mueller, R. Koch, and W. Jaross, "Expression of secretory 
group IIA phospholipase A2 in relation to the presence of microbial agents, macrophage infiltrates, and transcripts of proinflammatory cytokines in human aortic tissues," Arteriosclerosis, Thrombosis, and Vascular Biology, vol. 20, no. 3, pp. 751-762, 2000.

[110] E. Hurt-Camejo, S. Andersen, R. Standal et al., "Localization of nonpancreatic secretory phospholipase A2 in normal and atherosclerotic arteries: activity of the isolated enzyme on low-density lipoproteins," Arteriosclerosis, Thrombosis, and Vascular Biology, vol. 17, no. 2, pp. 300-309, 1997.

[111] M. Romano, E. Romano, S. Björkerud, and E. Hurt-Camejo, "Ultrastructural localization of secretory type II phospholipase A2 in atherosclerotic and nonatherosclerotic regions of human arteries," Arteriosclerosis, Thrombosis, and Vascular Biology, vol. 18, no. 4, pp. 519-525, 1998.

[112] G. C. Beck, B. A. Yard, J. Schulte et al., "Secreted phospholipases A2 induce the expression of chemokines in microvascular endothelium," Biochemical and Biophysical Research Communications, vol. 300, no. 3, pp. 731-737, 2003.

[113] K. Kugiyama, Y. Ota, K. Takazoe et al., "Circulating levels of secretory type II phospholipase A2 predict coronary events in patients with coronary artery disease," Circulation, vol. 100, no. 12, pp. 1280-1284, 1999.

[114] W. Koenig, C. Y. Vossen, Z. Mallat, H. Brenner, J. Benessiano, and D. Rothenbacher, "Association between type II secretory phospholipase A 2 plasma concentrations and activity and cardiovascular events in patients with coronary heart disease," European Heart Journal, vol. 30, no. 22, pp. 2742-2748, 2009.

[115] C. Raguenes-Nicol, F. Russo-Marie, G. Domage et al., "Antiinflammatory mechanism of alminoprofen: action on the phospholipid metabolism pathway," Biochemical Pharmacology, vol. 57, no. 4, pp. 433-443, 1999.

[116] M. J. B. M. Vervoordeldonk, I. M. Pineda Torra, A. J. Aarsman, and H. Van Den Bosch, "Aspirin inhibits expression of the interleukin- $1 \beta$-inducible group II phospholipase A2," FEBS Letters, vol. 397, no. 1, pp. 108-112, 1996.

[117] R. Dua and W. Cho, "Inhibition of human secretory class II phospholipase A2 by heparin," European Journal of Biochemistry, vol. 221, no. 1, pp. 481-490, 1994.

[118] W. Pruzanski, E. Stefanski, P. Vadas, T. F. McNamara, N. Ramamurthy, and L. M. Golub, "Chemically modified nonantimicrobial tetracyclines inhibit activity of phospholipases A2," Journal of Rheumatology, vol. 25, no. 9, pp. 1807-1812, 1998.

[119] O. Wiklund, L. Mattsson-Hultén, E. Hurt-Camejo, and J. Oscarsson, "Effects of simvastatin and atorvastatin on inflammation markers in plasma," Journal of Internal Medicine, vol. 251, no. 4, pp. 338-347, 2002.

[120] X. Chen, T. O. Scholl, and T. P. Stein, "Association of elevated serum ferritin levels and the risk of gestational diabetes mellitus in pregnant women: the Camden study," Diabetes Care, vol. 29, no. 5, pp. 1077-1082, 2006.

[121] R. J. Wood, "The iron-heart disease connection: is it dead or just hiding?" Ageing Research Reviews, vol. 3, no. 3, pp. 355367, 2004.

[122] M. C. Linder, K. J. Schaffer, M. Hazegh-Azam, C. Y. J. Zhou, T. N. Tran, and G. M. Nagel, "Serum ferritin: does it differ from tissue ferritin?" Journal of Gastroenterology and Hepatology, vol. 11, no. 11, pp. 1033-1036, 1996.

[123] M. J. Hynes and M. Ó Coinceanainn, "Investigation of the release of iron from ferritin by naturally occurring antioxidants," Journal of Inorganic Biochemistry, vol. 90, no. 1-2, pp. 18-21, 2002.

[124] K. D. Welch, C. A. Reilly, and S. D. Aust, "The role of cysteine residues in the oxidation of ferritin," Free Radical Biology and Medicine, vol. 33, no. 3, pp. 399-408, 2002.

[125] M. Rudeck, T. Volk, N. Sitte, and T. Grüne, "Ferritin oxidation in vitro: implication of iron release and degradation by the 20s proteasome," IUBMB Life, vol. 49, no. 5, pp. 451-456, 2000.

[126] T. N. Tran, S. K. Eubanks, K. J. Schaffer, C. Y. J. Zhou, and M. C. Linder, "Secretion of ferritin by rat hepatoma cells and its regulation by inflammatory cytokines and iron," Blood, vol. 90, no. 12, pp. 4979-4986, 1997.

[127] C. Beerenhout, O. Bekers, J. P. Kooman, F. M. Van Der Sande, and K. M. L. Leunissen, "A comparison between the soluble transferrin receptor, transferrin saturation and serum ferritin as markers of iron state in hemodialysis patients," Nephron, vol. 92, no. 1, pp. 32-35, 2002.

[128] M. Visser, L. M. Bouter, G. M. McQuillan, M. H. Wener, and T. B. Harris, "Elevated C-reactive protein levels in overweight and obese adults," Journal of the American Medical Association, vol. 282, no. 22, pp. 2131-2135, 1999.

[129] D. J. Fleming, P. F. Jacques, J. M. Massaro, R. B. D’Agostino Sr., P. W. F. Wilson, and R. J. Wood, "Aspirin intake and the use of serum ferritin as a measure of iron status," American Journal of Clinical Nutrition, vol. 74, no. 2, pp. 219-226, 2001.

[130] K. C. Sung, J. H. Kang, and H. S. Shin, "Relationship of Cardiovascular Risk Factors and Serum Ferritin with Creactive Protein," Archives of Medical Research, vol. 38, no. 1, pp. 121-125, 2007.

[131] J. T. Salonen, K. Nyyssonen, H. Korpela, J. Tuomilehto, R. Seppanen, and R. Salonen, "High stored iron levels are associated with excess risk of myocardial infarction in Eastern Finnish men," Circulation, vol. 86, no. 3, pp. 803-811, 1992.

[132] S. Kiechl, J. Willeit, G. Egger, W. Poewe, and F. Oberhollenzer, "Body iron stores and the risk of carotid atherosclerosis: prospective results from the bruneck study," Circulation, vol. 96, no. 10, pp. 3300-3307, 1997.

[133] P. Galan, N. Noisette, C. Estaquio et al., "Serum ferritin, cardiovascular risk factors and ischaemic heart diseases: a prospective analysis in the SU.VI.MAX (SUpplementation en VItamines et Minéraux AntioXydants) cohort," Public Health Nutrition, vol. 9, no. 1, pp. 70-74, 2006.

[134] C. T. Sempos, A. C. Looker, R. F. Gillum, D. L. McGee, C. V. Vuong, and C. L. Johnson, "Serum ferritin and death from all causes and cardiovascular disease: the NHANES II mortality study," Annals of Epidemiology, vol. 10, no. 7, pp. 441-448, 2000.

[135] A. Dominguez-Rodriguez, Tome M. Carrillo-Perez, C. Hernandez-Garcia et al., "Serum ferritin and acute coronary syndrome: a strong prognostic factor?" International Journal of Cardiology, vol. 152, no. 1, pp. 129-130, 2011.

[136] Y. Fan, J. Wang, L. Wei, B. He, C. Wang, and Binyao Wang, "Iron deficiency activates pro-inflammatory signaling in macrophages and foam cells via the p38 MAPK-NF- $\kappa \mathrm{B}$ pathway," International Journal of Cardiology, vol. 152, no. 1, pp. 49-55, 2010.

[137] H. L. Viener and A. P. Levy, "Haptoglobin genotype and the iron hypothesis of atherosclerosis," Atherosclerosis, vol. 216, no. 1, pp. 17-18, 2011.

[138] B. H. Bowman and A. Kurosky, "Haptoglobin: the evolutionary product of duplication, unequal crossing over, and point 
mutation," Advances in Human Genetics, vol. 12, pp. 189-453, 1982.

[139] A. P. Levy, R. Asleh, S. Blum et al., "Haptoglobin: basic and clinical aspects," Antioxidants and Redox Signaling, vol. 12, no. 2, pp. 293-304, 2010.

[140] M. Kristiansen, J. H. Graversen, C. Jacobsen et al., "Identification of the haemoglobin scavenger receptor," Nature, vol. 409, no. 6817, pp. 198-201, 2001.

[141] J. H. Graversen, M. Madsen, and S. K. Moestrup, “CD163: a signal receptor scavenging haptoglobin-hemoglobin complexes from plasma," International Journal of Biochemistry and Cell Biology, vol. 34, no. 4, pp. 309-314, 2002.

[142] R. Asleh, J. Guetta, S. Kalet-Litman, R. Miller-Lotan, and A. P. Levy, "Haptoglobin genotype- and diabetes-dependent differences in iron-mediated oxidative stress in vitro and in vivo," Circulation Research, vol. 96, no. 4, pp. 435-441, 2005.

[143] F. S. Boretti, P. W. Buehler, F. D’Agnillo et al., "Sequestration of extracellular hemoglobin within a haptoglobin complex decreases its hypertensive and oxidative effects in dogs and guinea pigs," Journal of Clinical Investigation, vol. 119, no. 8, pp. 2271-2280, 2009.

[144] J. H. Crawford, T. S. Isbell, Z. Huang et al., "Hypoxia, red blood cells, and nitrite regulate $\mathrm{NO}$-dependent hypoxic vasodilation," Blood, vol. 107, no. 2, pp. 566-574, 2006.

[145] G. J. Kato, “Haptoglobin halts hemoglobin's havoc," Journal of Clinical Investigation, vol. 119, no. 8, pp. 2140-2142, 2009.

[146] S. Blum, M. Vardi, J. B. Brown et al., "Vitamin e reduces cardiovascular disease in individuals with diabetes mellitus and the haptoglobin 2-2 genotype," Pharmacogenomics, vol. 11, no. 5, pp. 675-684, 2010.

[147] A. P. Levy, I. Hochberg, K. Jablonski et al., "Haptoglobin phenotype is an independent risk factor for cardiovascular disease in individuals with diabetes: the strong heart study," Journal of the American College of Cardiology, vol. 40, no. 11, pp. 1984-1990, 2002.

[148] A. Roguin, W. Koch, A. Kastrati, D. Aronson, A. Schomig, and A. P. Levy, "Haptoglobin genotype is predictive of major adverse cardiac events in the 1-year period after percutaneous transluminal coronary angioplasty in individuals with diabetes," Diabetes Care, vol. 26, no. 9, pp. 2628-2631, 2003.

[149] M. Suleiman, D. Aronson, R. Asleh et al., "Haptoglobin polymorphism predicts 30-day mortality and heart failure in patients with diabetes and acute myocardial infarction," Diabetes, vol. 54, no. 9, pp. 2802-2806, 2005.

[150] U. Milman, S. Blum, C. Shapira et al., "Vitamin E supplementation reduces cardiovascular events in a subgroup of middle-aged individuals with both type 2 diabetes mellitus and the haptoglobin 2-2 genotype: a prospective doubleblinded clinical trial," Arteriosclerosis, Thrombosis, and Vascular Biology, vol. 28, no. 2, pp. 341-347, 2008.

[151] T. Costacou, R. E. Ferrell, and T. J. Orchard, "Haptoglobin genotype a determinant of cardiovascular complication risk in type 1 diabetes," Diabetes, vol. 57, no. 6, pp. 1702-1706, 2008.

[152] A. P. Levy, I. Hochberg, K. Jablonski et al., "Haptoglobin phenotype is an independent risk factor for cardiovascular disease in individuals with diabetes: the strong heart study," Journal of the American College of Cardiology, vol. 40, no. 11, pp. 1984-1990, 2002.

[153] F. M. Nakhoul, R. Zoabi, Y. Kanter et al., "Haptoglobin phenotype and diabetic nephropathy," Diabetologia, vol. 44, no. 5, pp. 602-604, 2001.
[154] A. Roguin, I. Hochberg, E. Nikolsky et al., "Haptoglobin phenotype as a predictor of restenosis after percutaneous transluminal coronary angioplasty," American Journal of Cardiology, vol. 87, no. 3, pp. 330-332, 2001.

[155] D. D. Bacquer, G. Backer, M. D. Langlois, J. Delanghe, H. Kesteloot, and M. Kornitzer, "Haptoglobin polymorphism as a risk factor for coronary heart disease mortality," Atherosclerosis, vol. 157, no. 1, pp. 161-166, 2001.

[156] P. L. Fox, B. Mazumder, E. Ehernwal et al., "Ceruplasmin and cardiovascular disease," Free Radical Biology \& Medicine, vol. 28, no. 12, pp. 1735-1744, 2000.

[157] L. Rydén, "Ceruloplasmin," in Copper Proteins and Copper Enzymes, Volume III, R. Lontie, Ed., pp. 37-100, CRC Press, Boca Raton, Fla, USA, 1984.

[158] P. L. Fox, C. Mukhopadhyay, and E. Ehrenwald, "Structure, oxidant activity, and cardiovascular mechanisms of human ceruloplasmin," Life Sciences, vol. 56, no. 21, pp. 1749-1758, 1995.

[159] E. Frieden and H. S. Hsieh, "The biological role of ceruloplasmin and its oxidase activity," Advances in Experimental Medicine and Biology, vol. 74, pp. 505-529, 1976.

[160] W. H. Tang, Y. Wu, S. J. Nicholls, and S. L. Hazen, "Serum Cp: independently predicts cardiovascular risk in stable cardiac patients," Circulation, vol. 122, 2010, Meeting Abstract Supplement, abstract no. 18791.

[161] S. J. Adelstein, T. L. Coombs, and B. L. Vallee, "Metalloenzymes and myocardial infarction. I. The relation between serum copper and ceruloplasmin and its catalytic activity," The New England Journal of Medicine, vol. 255, no. 3, pp. 105109, 1956.

[162] J. Bustamante, M. C. Martin, and J. Fernandez, "Zinc, copper and ceruloplasmin in arteriosclerosis," Biomedicine Express, vol. 25, no. 7, pp. 244-245, 1976.

[163] J. T. Powell, B. R. Muller, and R. M. Greenhalgh, "Acute phase proteins in patients with abdominal aortic aneurysms," Journal of Cardiovascular Surgery, vol. 28, no. 5, pp. 528-530, 1987.

[164] N. Jayakumari, V. Ambikakumari, K. G. Balakrishnan, and K. Subramonia Iyer, "Antioxidant status in relation to free radical production during stable and unstable anginal syndromes," Atherosclerosis, vol. 94, no. 2-3, pp. 183-190, 1992.

[165] J. J. F. Belch, M. Chopra, S. Hutchison et al., "Free radical pathology in chronic arterial disease," Free Radical Biology and Medicine, vol. 6, no. 4, pp. 375-378, 1989.

[166] J. T. Salonen, R. Salonen, H. Korpela, S. Suntioinen, and J. Tuomilehto, "Serum copper and the risk of acute myocardial infarction: a prospective population study in men in Eastern Finland," American Journal of Epidemiology, vol. 134, no. 3, pp. 268-276, 1991.

[167] J. T. Salonen, R. Salonen, K. Seppänen, M. Kantola, S. Suntioinen, and H. Korpela, "Interactions of serum copper, selenium, and low density lipoprotein cholesterol in atherogenesis," British Medical Journal, vol. 302, no. 6779, pp. 756760, 1991.

[168] J. Swain and J. M. C. Gutteridge, "Prooxidant iron and copper, with ferroxidase and xanthine oxidase activities in human atherosclerotic material," FEBS Letters, vol. 368, no. 3, pp. 513-515, 1995.

[169] C. Smith, M. J. Mitchinson, O. I. Aruoma, and B. Halliwell, "Stimulation of lipid peroxidation and hydroxyl-radical generation by the contents of human atherosclerotic lesions," Biochemical Journal, vol. 286, no. 3, pp. 901-905, 1992. 
[170] A. Ziakas, S. Gavrilidis, E. Souliou et al., "Ceruloplasmin is a better predictor of the long-term prognosis compared with fibrinogen, CRP, and IL-6 in patients with severe unstable angina," Angiology, vol. 60, no. 1, pp. 50-59, 2009.

[171] N. Jayakumari, V. Ambikakumari, K. G. Balakrishnan, and K. Subramonia Iyer, "Antioxidant status in relation to free radical production during stable and unstable anginal syndromes," Atherosclerosis, vol. 94, no. 2-3, pp. 183-190, 1992.

[172] J. T. Salonen, R. Salonen, K. Seppanen, M. Kantola, S. Suntioinen, and H. Korpela, "Interactions of serum copper, selenium, and low density lipoprotein cholesterol in atherogenesis," British Medical Journal, vol. 302, no. 6779, pp. 756760, 1991.

[173] M. J. Saraiva, "Transthyretin amyloidosis: a tale of weak interactions," FEBS Letters, vol. 498, no. 2-3, pp. 201-203, 2001.

[174] A. Mezzetti, M. D. Guglielmi, S. D. Pierdomenico et al., "Increased systemic oxidative stress after elective endarterectomy - relation to vascular healing and remodeling," Arteriosclerosis, Thrombosis, and Vascular Biology, vol. 19, no. 11, pp. 2659-2665, 1999.

[175] A. G. Shaper, S. G. Wannamethee, and P. H. Whincup, "Serum albumin and risk of stroke, coronary heart disease, and mortality: the role of cigarette smoking," Journal of Clinical Epidemiology, vol. 57, no. 2, pp. 195-202, 2004.

[176] L. H. Kuller, R. P. Tracy, J. Shaten, and E. N. Meilahn, "Relation of C-reactive protein and coronary heart disease in the MRFIT nested case-control study," American Journal of Epidemiology, vol. 144, no. 6, pp. 537-547, 1996.

[177] J. Danesh, R. Collins, P. Appleby, and R. Peto, "Association of fibrinogen, C-reactive protein, albumin, or leukocyte count with coronary heart disease: meta-analyses of prospective studies," Journal of the American Medical Association, vol. 279, no. 18, pp. 1477-1482, 1998.

[178] R. F. Gillum, D. D. Ingram, and D. M. Makuc, "Relation between serum albumin concentration and stroke incidence and death: the NHANES I epidemiologic follow-up study," American Journal of Epidemiology, vol. 140, no. 10, pp. 876888, 1994.

[179] P. S. Lim, Y. M. Cheng, and S. M. Yang, "Impairments of the biological properties of serum albumin in patients on haemodialysis," Nephrology, vol. 12, no. 1, pp. 18-24, 2007.

[180] M. P. Weijenberg, E. J. M. Feskens, J. H. M. Souverijn, and D. Kromhout, "Serum albumin, coronary heart disease risk, and mortality in an elderly cohort," Epidemiology, vol. 8, no. 1, pp. 87-92, 1997.

[181] B. Halliwell and J. M. C. Gutteridge, "The antioxidants of human extracellular fluids," Archives of Biochemistry and Biophysics, vol. 280, no. 1, pp. 1-8, 1990.

[182] L. H. Kuller, J. E. Eichner, T. J. Orchard, G. A. Grandits, L. McCallum, and R. P. Tracy, "The relation between serum albumin levels and risk of coronary heart disease in the multiple risk factor intervention trial," American Journal of Epidemiology, vol. 134, no. 11, pp. 1266-1277, 1991.

[183] A. Phillips, A. G. Shaper, and P. H. Whincup, "Association between serum albumin and mortality from cardiovascular disease, cancer, and other causes," The Lancet, vol. 2, no. 8677, pp. 1434-1436, 1989.

[184] L. Djoussé, K. J. Rothman, L. A. Cupples, D. Levy, and R. C. Ellison, "Serum albumin and risk of myocardial infarction and all-cause mortality in the framingham offspring study," Circulation, vol. 106, no. 23, pp. 2919-2924, 2002.
[185] A.T. Høstmark, "Serum albumin and prevalence of coronary heart disease: a population-based, cross sectional study," Norsk Epidemiologi, vol. 13, no. 1, pp. 107-113, 2003.

[186] V. Menon, X. Wang, T. Greene et al., "Relationship between C-reactive protein, albumin, and cardiovascular disease in patients with chronic kidney disease," American Journal of Kidney Diseases, vol. 42, no. 1, pp. 44-52, 2003.

[187] D. Docci, R. Bilancioni, A. Buscaroli et al., "Elevated serum levels of C-reactive protein in hemodialysis patients," Nephron, vol. 56, no. 4, pp. 364-367, 1990.

[188] A. Fine, "Relevance of C-reactive protein levels in peritoneal dialysis patients," Kidney International, vol. 61, no. 2, pp. 615-620, 2002.

[189] M. Haubitz, R. Brunkhorst, E. Wrenger, P. Froese, M. Schulze, and K. M. Koch, "Chronic induction of C-reactive protein by hemodialysis, but not by peritoneal dialysis therapy," Peritoneal Dialysis International, vol. 16, no. 2, pp. 158-162, 1996.

[190] T. A. Ikizler, R. L. Wingard, J. Harvell, Y. Shyr, and R. M. Hakim, "Association of morbidity with markers of nutrition and inflammation in chronic hemodialysis patients: a prospective study," Kidney International, vol. 55, no. 5, pp. 1945-1951, 1999.

[191] M. M. Avram, N. Mittman, L. Bonomini, J. Chattopadhyay, and P. Fein, "Markers for survival in dialysis: a seven-year prospective study," American Journal of Kidney Diseases, vol. 26, no. 1, pp. 209-219, 1995.

[192] R. N. Foley, P. S. Parfrey, J. D. Harnett, G. M. Kent, D. C. Murray, and P. E. Barre, "Hypoalbuminemia, cardiac morbidity, and mortality in end-stage renal disease," Journal of the American Society of Nephrology, vol. 7, no. 5, pp. 728736, 1996.

[193] R. M. Bologa, D. M. Levine, T. S. Parker et al., "Interleukin-6 predicts hypoalbuminemia, hypocholesterolemia, and mortality in hemodialysis patients," American Journal of Kidney Diseases, vol. 32, no. 1, pp. 107-114, 1998.

[194] A. R. Qureshi, A. Alvestrand, A. Danielsson et al., "Factors predicting malnutrition in hemodialysis patients: a crosssectional study," Kidney International, vol. 53, no. 3, pp. 773782, 1998.

[195] G. A. Kaysen, J. A. Dubin, H. G. Müller, W. E. Mitch, and N. W. Levin, "Levels of $\alpha 1$ acid glycoprotein and ceruloplasmin predict future albumin levels in hemodialysis patients," Kidney International, vol. 60, no. 6, pp. 2360-2366, 2001.

[196] S. B. Kim, W. S. Yang, and J. S. Park, "Role of hypoalbuminemia in the genesis of cardiovascular disease in dialysis patients," Peritoneal Dialysis International, vol. 19, no. 2, supplement, pp. S144-S149, 1999.

[197] S. Y. Hong and D. H. Yang, "Lipoprotein(a) levels and fibrinolytic activity in patients with nephrotic syndrome," Nephron, vol. 69, no. 2, pp. 125-130, 1995.

[198] W. S. Yang, S. B. Kim, W. K. Min, S. Park, M. S. Lee, and J. S. Park, "Atherogenic lipid profile and lipoprotein(a) in relation to serum albumin in haemodialysis patients," Nephrology Dialysis Transplantation, vol. 10, no. 9, pp. 1668-1671, 1995.

[199] S. B. Kim, W. S. Yang, S. K. Lee, H. S. Chi, and J. S. Park, "Effect of increasing serum albumin on haemostatic factors synthesized in the liver in CAPD patients," Nephrology Dialysis Transplantation, vol. 13, no. 8, pp. 2053-2058, 1998.

[200] P. Stenvinkel, L. Berglund, S. Ericsson, A. Alvestrand, B. Angelin, and M. Eriksson, "Low-density lipoprotein metabolism and its association to plasma lipoprotein(a) 
in the nephrotic syndrome," European Journal of Clinical Investigation, vol. 27, no. 2, pp. 169-177, 1997.

[201] W. S. Yang, S. B. Kim, W. K. Min, and J. S. Park, "Effect of increasing serum albumin onserum lipoprotein (a) concentration in patients on continuous ambulatory peritoneal dialysis," American Journal of Kidney Diseases, vol. 30, pp. 507-513, 1997.

[202] J. H. Baxter, H. C. Goodman, and J. C. Allen, "Effects of infusions of serum albumin on serum lipids and lipoproteins in nephrosis," The Journal of Clinical Investigation, vol. 40, pp. 490-498, 1961.

[203] J. C. Allen, J. H. Baxter, and H. C. Goodman, "Effects of dextran, polyvinylpyrrolidone and gamma globulin on the hyperlipidemia of experimental nephrosis," The Journal of Clinical Investigation, vol. 40, pp. 499-508, 1961.

[204] A. Kanfer, D. Kleinknecht, M. Broyer, and F. Josso, "Coagulation studies in 45 cases of nephrotic syndrome without uremia," Thrombosis et Diathesis Haemorrhagica, vol. 24, no. 3, pp. 562-571, 1970.

[205] K. J. Kim, W. S. Yang, S. B. Kim, S. K. Lee, and J. S. Park, "Fibrinogen and fibrinolytic activity in CAPD patients with atherosclerosis and its correlation with serum albumin," Peritoneal Dialysis International, vol. 17, no. 2, pp. 157-161, 1997.

[206] L. R. Pickart and M. M. Thaler, "Free fatty acids and albumin as mediators of thrombin stimulated fibrinogen synthesis," American Journal of Physiology, vol. 230, no. 4, pp. 996-1002, 1976.

[207] S. D. Johnson, C. E. Lucas, and S. J. Gerrick, "Altered coagulation after albumin supplements for treatment of oligemic shock," Archives of Surgery, vol. 114, no. 4, pp. 379383, 1979.

[208] S. B. Kim, H. S. Chi, J. S. Park, C. D. Hong, and W. S. Yang, "Effect of increasing serum albumin on plasma D-dimer, von Willebrand factor, and platelet aggregation in CAPD patients," American Journal of Kidney Diseases, vol. 33, no. 2, pp. 312-317, 1999.

[209] N. U. Bang, C. W. Trygstad, J. E. Schroeder, R. O. Heidenreich, and B. M. Csiscko, "Enhanced platelet function in glomerular renal disease," The Journal of Laboratory and Clinical Medicine, vol. 81, no. 5, pp. 651-660, 1973.

[210] K. A. Jorgensen and E. Stoffersen, "On the inhibitory effect of albumin on platelet aggregation," Thrombosis Research, vol. 17, no. 1-2, pp. 13-18, 1980.

[211] S. B. Kim, W. S. Yang, E. S. Kang, W. K. Min, and J. S. Park, "Lipoprotein (a) and Apo A phenotypes in patients with endstage renal disease," Peritoneal Dialysis International, vol. 17, pp. 236-242, 1997.

[212] A. J. Marcus, "Platelet activation," in Atherosclerosis and Coronary Artery Disease, V. Fuster, R. Ross, and E. J. Topol, Eds., pp. 607-637, Raven, Philadelphia, Pa, USA, 1st edition, 1996.

[213] N. Yoshida and N. Aoki, "Release of arachidonic acid from human platelets. A key role for the potentiation of platelet aggregability in normal subjects as well as in those with nephrotic syndrome," Blood, vol. 52, no. 5, pp. 969-977, 1978.

[214] G. Remuzzi, G. Mecca, D. Marchesi et al., "Platelet hyperaggregability and the nephrotic syndrome," Thrombosis Research, vol. 16, no. 3-4, pp. 345-354, 1979.

[215] A. Schieppati, P. Dodesini, A. Benigni et al., "The metabolism of arachidonic acid by platelets in nephrotic syndrome," Kidney International, vol. 25, no. 4, pp. 671-676, 1984.
[216] Z. Duniec and J. Robak, "Albumin is one of lipoxygenase inhibitors in serum," Polish Journal of Pharmacology and Pharmacy, vol. 36, no. 5, pp. 465-471, 1984.

[217] C. G. Groth, "The effect of infused albumin and Rheomacrodex on factors governing the flow properties of the human blood," Acta Chirurgica Scandinavica, vol. 131, no. 4, pp. 290-297, 1966.

[218] E. McGinley, G. D. O. Lowe, and M. Boulton Jones, "Blood viscosity and haemostasis in the nephrotic syndrome," Thrombosis and Haemostasis, vol. 49, no. 3, pp. 155-157, 1983.

[219] J. A. Joles, N. Willekes-Koolschijn, and H. A. Koomans, "Hypoalbuminemia causes high blood viscosity by increasing red cell lysophosphatidylcholine," Kidney International, vol. 52, no. 3, pp. 761-770, 1997.

[220] M. Feriani, P. L. Kimmel, J. Kurantsin-Mills, and J. P. Bosch, "Effect of renal replacement therapy on viscosity in end-stage renal disease patients," American Journal of Kidney Diseases, vol. 19, no. 2, pp. 131-139, 1992.

[221] M. P. Gordge, A. Patel, R. W. Faint, P. B. Rylance, and G. H. Neild, "Blood hyperviscosity and its relationship to progressive renal failure in patients with diabetic nephropathy," Diabetic Medicine, vol. 7, no. 10, pp. 880-886, 1990.

[222] A. Fleck and F. R. Path, "Acute phase response: implications for nutrition and recovery," Nutrition, vol. 4, no. 2, pp. 109117, 1988.

[223] J. Y. Yeun and G. A. Kaysen, "Acute phase proteins and peritoneal dialysate albumin loss are the main determinants of serum albumin in peritoneal dialysis patients," American Journal of Kidney Diseases, vol. 30, no. 6, pp. 923-927, 1997.

[224] A. R. Folsom, J. Ma, J. H. Eckfeldt, F. J. Nieto, P. A. Metcalf, and R. W. Barnes, "Low serum albumin: association with diabetes mellitus and other cardiovascular risk factors but not with prevalent cardiovascular disease or carotid artery intima-media thickness," Annals of Epidemiology, vol. 5, no. 3, pp. 186-191, 1995.

[225] C. Rapezzi, C. C. Quarta, L. Riva et al., "Transthyretin-related amyloidoses and the heart: a clinical overview," Nature Reviews Cardiology, vol. 7, no. 7, pp. 398-408, 2010.

[226] S. H. Ingbar, "Pre-albumin: a thyroxinebinding protein of human plasma," Endocrinology, vol. 63, no. 2, pp. 256-259, 1958.

[227] L. Rask, H. Anundi, and P. A. Peterson, "The primary structure of the human retinol-binding protein," FEBS Letters, vol. 104, no. 1, pp. 55-58, 1979.

[228] H. E. Schultze and J. F. Heremans, Molecular Biology of Human Proteins, Elsevier, London, UK, 1966.

[229] P. W. Dickson, A. R. Aldred, and P. D. Marley, "High prealbumin and transferrin mRNA levels in the choroid plexus of rat brain," Biochemical and Biophysical Research Communications, vol. 127, no. 3, pp. 890-895, 1985.

[230] J. Robbins, “Thyroxine-binding proteins," Progress in Clinical and Biological Research, vol. 5, pp. 331-355, 1976.

[231] M. D. Benson and J. C. Kincaid, "The molecular biology and clinical features of amyloid neuropathy," Muscle and Nerve, vol. 36, no. 4, pp. 411-423, 2007.

[232] P. Westermark, K. Sletten, B. Johansson, and G. G. Cornwell, "Fibril in senile systemic amyloidosis is derived from normal transthyretin," Proceedings of the National Academy of Sciences of the United States of America, vol. 87, no. 7, pp. 2843-2845, 1990.

[233] X. Hou, M. I. Aguilar, and D. H. Small, "Transthyretin and familial amyloidotic polyneuropathy: recent progress in 
understanding the molecular mechanism of neurodegeneration," FEBS Journal, vol. 274, no. 7, pp. 1637-1650, 2007.

[234] Y. Ando, M. Nakamura, and S. Araki, "Transthyretin-related familial amyloidotic polyneuropathy," Archives of Neurology, vol. 62, no. 7, pp. 1057-1062, 2005.

[235] P. Westermark, M. D. Benson, J. N. Buxbaum et al., "A primer of amyloid nomenclature," Amyloid, vol. 14, no. 3, pp. 179183, 2007.

[236] R. H. Falk and S. W. Dubrey, "Amyloid heart disease," Progress in Cardiovascular Diseases, vol. 52, no. 4, pp. 347-361, 2010.

[237] K. B. Shah, Y. Inoue, and M. R. Mehra, "Amyloidosis and the heart: a comprehensive review," Archives of Internal Medicine, vol. 166, no. 17, pp. 1805-1813, 2006.

[238] C. Rapezzi, G. Merlini, C. C. Quarta et al., "Systemic cardiac amyloidoses: disease profiles and clinical courses of the 3 main types," Circulation, vol. 120, no. 13, pp. 1203-1212, 2009.

[239] J. Koyama, P. A. Ray-Sequin, R. Davidoff, and R. H. Falk, "Usefulness of pulsed tissue Doppler imaging for evaluating systolic and diastolic left ventricular function in patients with AL (primary) amyloidosis," American Journal of Cardiology, vol. 89, no. 9, pp. 1067-1071, 2002.

[240] A. V. Kristen, J. B. Perz, S. O. Schonland et al., "Non-invasive predictors of survival in cardiac amyloidosis," European Journal of Heart Failure, vol. 9, no. 6-7, pp. 617-624, 2007.

[241] M. R. Almeida, L. Gales, A. M. Damas, I. Cardoso, and M. J. Saraiva, "Small transthyretin (TTR) ligands as possible therapeutic agents in TTR amyloidoses," Current Drug Targets, vol. 4, no. 5, pp. 587-596, 2005.

[242] T. Mairal, J. Nieto, M. Pinto et al., "Iodine atoms: a new molecular feature for the design of potent transthyretin fibrillogenesis inhibitors," PLOS ONE, vol. 4, no. 1, article e4124, 2009.

[243] A. M. Johnson, G. Merlini, J. Sheldon, and K. Ichihara, "Clinical indications for plasma protein assays: transthyretin (prealbumin) in inflammation and malnutrition-international federation of clinical chemistry and laboratory medicine (IFCC): IFCC scientific division committee on plasma proteins (C-PP)," Clinical Chemistry and Laboratory Medicine, vol. 45, no. 3, pp. 419-426, 2007.

[244] P. Aisen, "Transferrin, the transferrin receptor, and the uptake of iron by cells," Metal Ions in Biological Systems, vol. 35, pp. 585-631, 1998.

[245] M. Ahmed, Detection of in vitro and in vivo oxidative modifications of ferritin and transferrin by mass spectrometry: hereditary hemochromatosis as a model, Ph.D. thesis, 2007.

[246] M. Thevis, R. R. Ogorzalek Loo, and J. A. Loo, "Mass spectrometric characterization of transferrins and their fragments derived by reduction of disulfide bonds," Journal of the American Society for Mass Spectrometry, vol. 14, no. 6, pp. 635-647, 2003.

[247] R. Pakdaman, F. B. Abdallah, and J. M. El Hage Chahine, "Transferrin, is a mixed chelate-protein ternary complex involved in the mechanism of iron uptake by serumtransferrin in vitro?" Journal of Molecular Biology, vol. 293, no. 5, pp. 1273-1284, 1999.

[248] A. Van Campenhout, C. M. Van Campenhout, A. R. Lagrou, and B. Manuel-Y-Keenoy, "Transferrin modifications and lipid peroxidation: implications in diabetes mellitus," Free Radical Research, vol. 37, no. 10, pp. 1069-1077, 2003.

[249] J. K. Brieland and J. C. Fantone, "Ferrous iron release from transferrin by human neutrophil-derived superoxide anion: effect of $\mathrm{pH}$ and iron saturation," Archives of Biochemistry and Biophysics, vol. 284, no. 1, pp. 78-83, 1991.

[250] M. Kar and A. S. Chakraborti, "Release of iron from haemoglobin-a possible source of free radicals in diabetes mellitus," Indian Journal of Experimental Biology, vol. 37, no. 2, pp. 190-192, 1999.

[251] P. Martin, C. Walton, C. Chapman, H. J. Bodansky, and M. H. Stickland, "Increased urinary excretion of transferrin in children with Type 1 diabetes mellitus," Diabetic Medicine, vol. 7, no. 1, pp. 35-40, 1990.

[252] M. J. O’Donnell, P. Martin, C. M. Florkowski et al., "Urinary transferrin excretion in Type 1 (insulin-dependent) diabetes mellitus," Diabetic Medicine, vol. 8, no. 7, pp. 657-661, 1991.

[253] C. K. Cheung, C. S. Cockram, V. T. F. Yeung, and R. Swaminathan, "Urinary excretion of transferrin by non-insulindependent diabetics: a marker for early complications?" Clinical Chemistry, vol. 35, no. 8, pp. 1672-1674, 1989.

[254] C. P. McCormick, J. C. Konen, and Z. K. Shihabi, "Microtransferrinuria and microalbuminuria: I. In the diabetic human," Clinical Physiology and Biochemistry, vol. 8, no. 2, pp. 53-58, 1990.

[255] A. M. Bernard, A. A. Amor, J. Goemaere-Vanneste et al., "Microtransferrinuria is a more sensitive indicator of early glomerular damage in diabetes than microalbuminuria," Clinical Chemistry, vol. 34, no. 9, pp. 1920-1921, 1988.

[256] G. Cartei, D. Causarano, and R. Naccarato, "Transferrin behaviour in primary haemochromatosis," Experientia, vol. 31, no. 3, pp. 373-375, 1975.

[257] R. G. Batey, P. L. C. Fong, S. Shamir, and S. Sherlock, "A nontransferrin-bound serum iron in idiopathic hemochromatosis," Digestive Diseases and Sciences, vol. 25, no. 5, pp. 340346, 1980. 


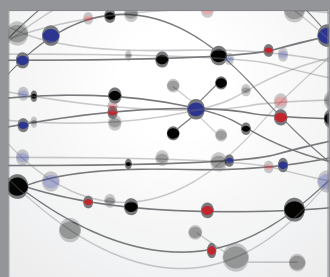

The Scientific World Journal
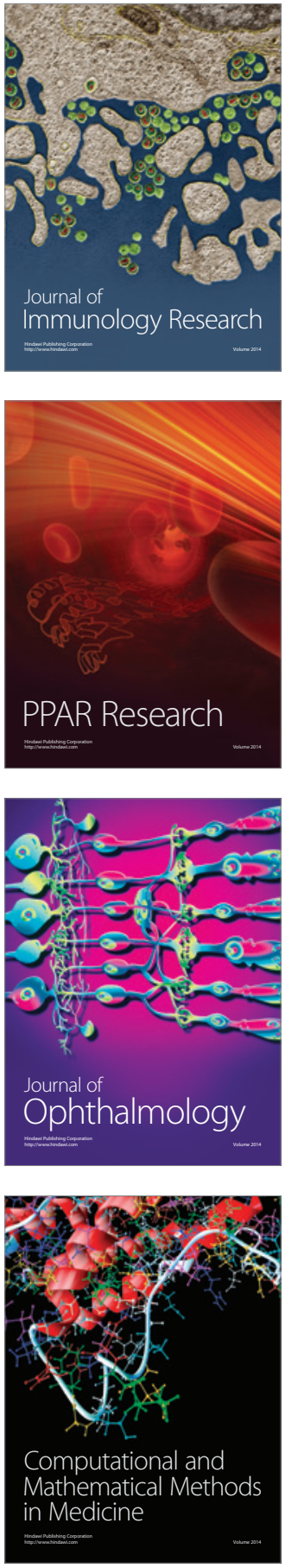

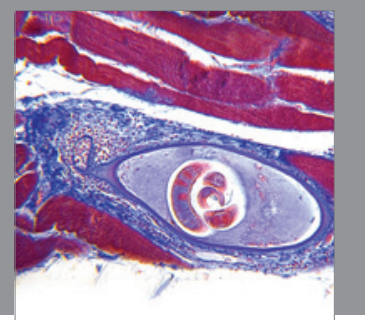

Gastroenterology

Research and Practice
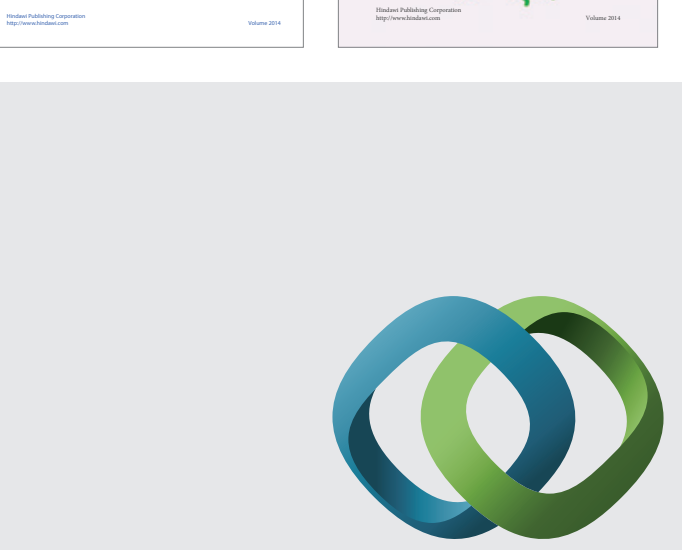

\section{Hindawi}

Submit your manuscripts at

http://www.hindawi.com
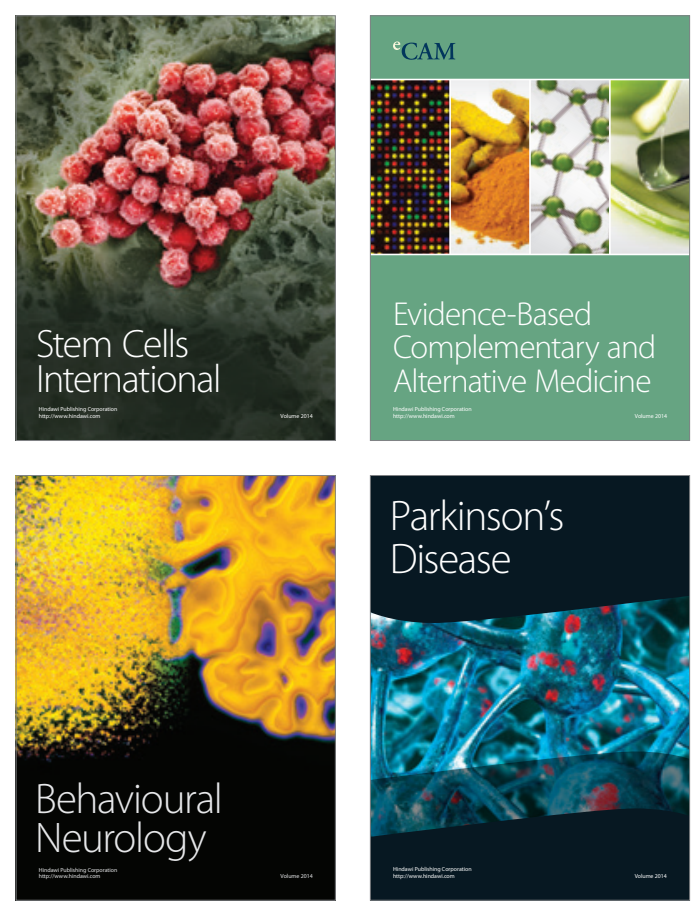

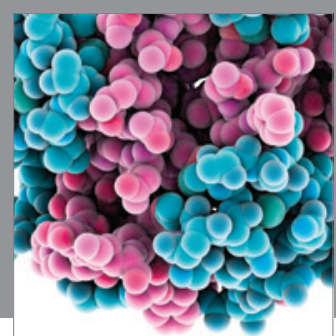

Journal of
Diabetes Research

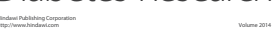

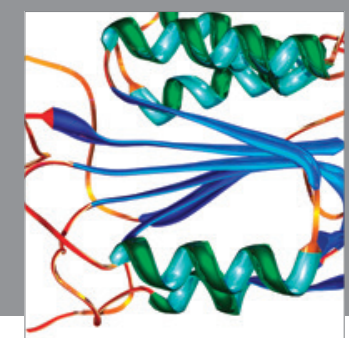

Disease Markers
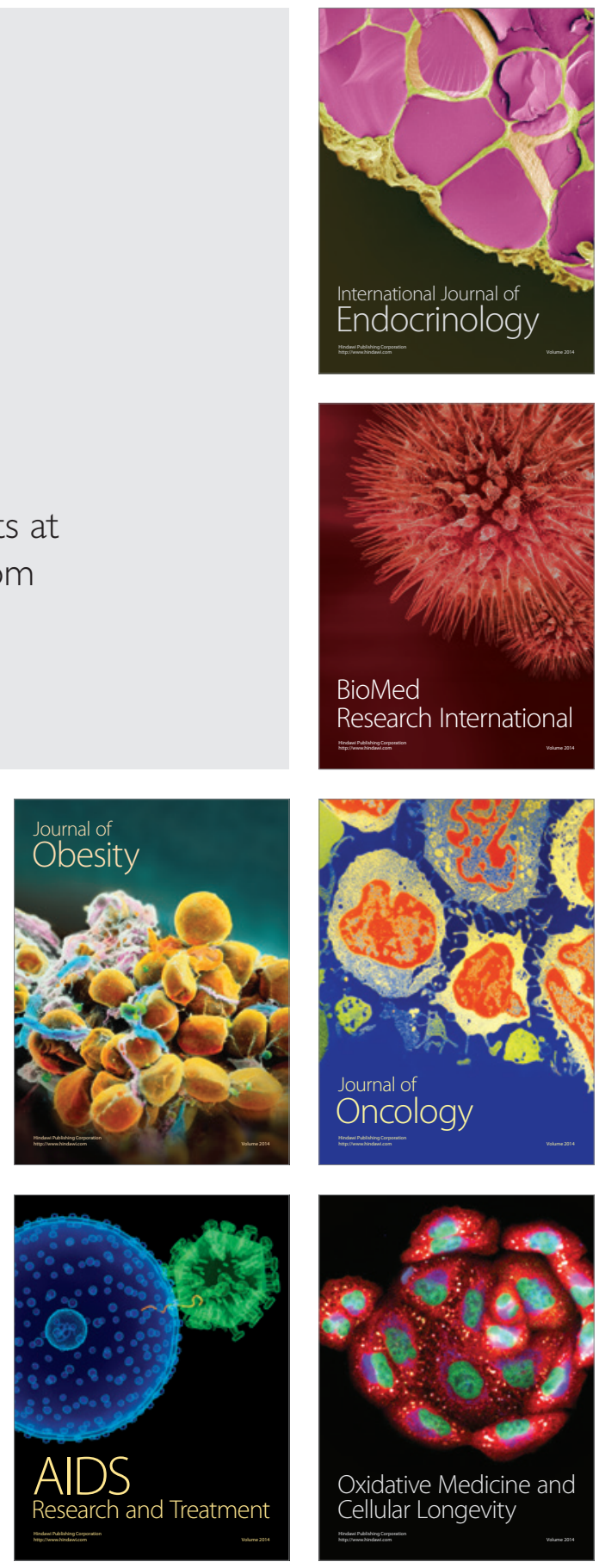